
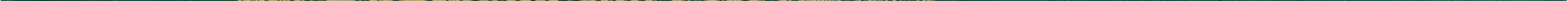


\section{KUML 1991-92}

Årbog for Jysk Arkæologisk Selskab

With summaries in English 
Redaktion: Hans Jørgen Madsen og Birgit M. Rasmussen

Redaktionsudvalg:

Jens Henrik Bech, Thisted

Steen Hvass, Vejle

Stig Jensen, Ribe

Erik Johansen, Aalborg

Steen W. Andersen, Haderslev

Lay-out og omslag: Jorgen Mührmann-Lund

Grafisk tilrettelagggelse: Elsebet Morville

Tryk: Special-Trykkeriet Viborg a-s

Skrift: Bembo 11/12

Papir: Stora G-Print $120 \mathrm{~g}$

Copyright 1994 by Jysk Arkaologisk Selskab

ISBN 87-7288-575-0

ISSN 0454-6245 


\section{Indhold/Contents}

Flemming Kaul: Ritualer med menneskeknogler i yngre stenalder ........................... 7

Neolithic Rituals involving Human Bones ................................................ 50

Anne Birgitte Sorensen: Enkeltgrave fra Rødding-egnen ...................................... 53

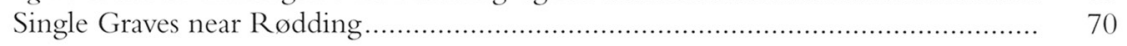

Bent Aaby, David Robinson og Anne Bloch Jørgensen: En gård fra førromersk jernalder og det omgivende landskab.....

A Pre-Roman Iron Age Settlement at Børglumvej, Århus:

Archaeology and Environment.

Orla Madsen: Søndervang ved Bjerre

En østjysk gravplads fra yngre germansk jernalder og vikingetid

Søndervang at Bjerre. A Cemetery from the Late Germanic and Viking periods in eastern Jutland ....

Bjarne Lonborg: Fremstillingen af vikingetidens skålformede fibler

The method of production of Viking Age tortoise brooches

Annette Hoff og Jens Jeppesen: Todderup

En udgravet torpbebyggelse og torperne historisk belyst

Todderup. The Excavation of a "torp" and the place of torps in history

Jysk Arkæologisk Selskab 1991 og 1992 


\title{
Ritualer med menneskeknogler i yngre stenalder
}

\author{
Af Flemming Kaul
}

Igennem hele den arkæologiske forsknings historie har skeletfund tiltrukket sig en særlig opmærksomhed blandt både læg og lærd. For den nordiske stenalders vedkommende synes denne fundgruppe dog at have ført en vis skyggetilværelse. Menneskeknoglerne i sig selv har sjældent stået i centrum, når et gravfund eller offerfund blev fremlagt og drøftet, og ved publiceringen af knoglefund, har de rent antropologiske indfaldsvinkler haft størst bevågenhed. Knoglefundene er imidlertid også af betydning for forståelsen af ritualerne i de neolitiske samfund.

Nærværende arbejde indledes med fremlæggelsen af knoglefundene fra en dysse i Hareskoven ved København, hvor de fundne knogler fremviser en bemærkelsesværdig fordeling af knogletyperne. Herefter publiceres et fund fra jættestuen Jordehøj på Møn, der fortæller om særlige ritualer med menneskeknogler. Nedlæggelsen af disse knogler har fundet sted i enkeltgravskultur eller senneolitikum.

Derefter ses på andre vidnesbyrd om ritualer med knogler fra stenalderen. Udover knoglefund fra den nordiske tragtbægerkultur fremlægges samtidige fund fra Tyskland, Frankrig og Storbritanien. Især i Storbritanien har denne fundkategori indtaget en mere central plads, og det er derfor naturligt især herfra at inddrage fund, der kan være af betydning for tolkningen af de nordiske fund. Endelig gennemgås en række knoglefund fra enkeltgravskultur og senneolitikum, der ligeledes må anses for vidnesbyrd om særlige ritualer omkring menneskeknogler. Af behandlingen fremgår det, at ritualer med udvalgte menneskeknogler, var et udbredt fænomen i Europas stenalder.

\section{Knoglefundene fra dyssen Trekroner og jættestuen Jordehøj}

\section{Trekroner, Hareskoven}

Fundene fra den ødelagte dysse Trekroner i Hareskoven vest for København hører til blandt de fă fund af menneskeknogler fra vore megalitgrave, hvor knoglematerialet er blevet analyseret (1). Dyssen, der undersøgtes af Nationalmuseet i efteråret 1981 (2) har tidligere været omtalt i anden sammenhæng (Kaul \& Krogh 1990 s. 246-251).

Selvom der er tale om et ødelagt anlæg, så må flere mere eller mindre væltede og kløvede randsten angive, at vi står overfor en mindre øst-vest-orienteret langdysse med målene ca. 12,5x8,5 m (fig. 1). Udskredne sandstensfliser udenfor 


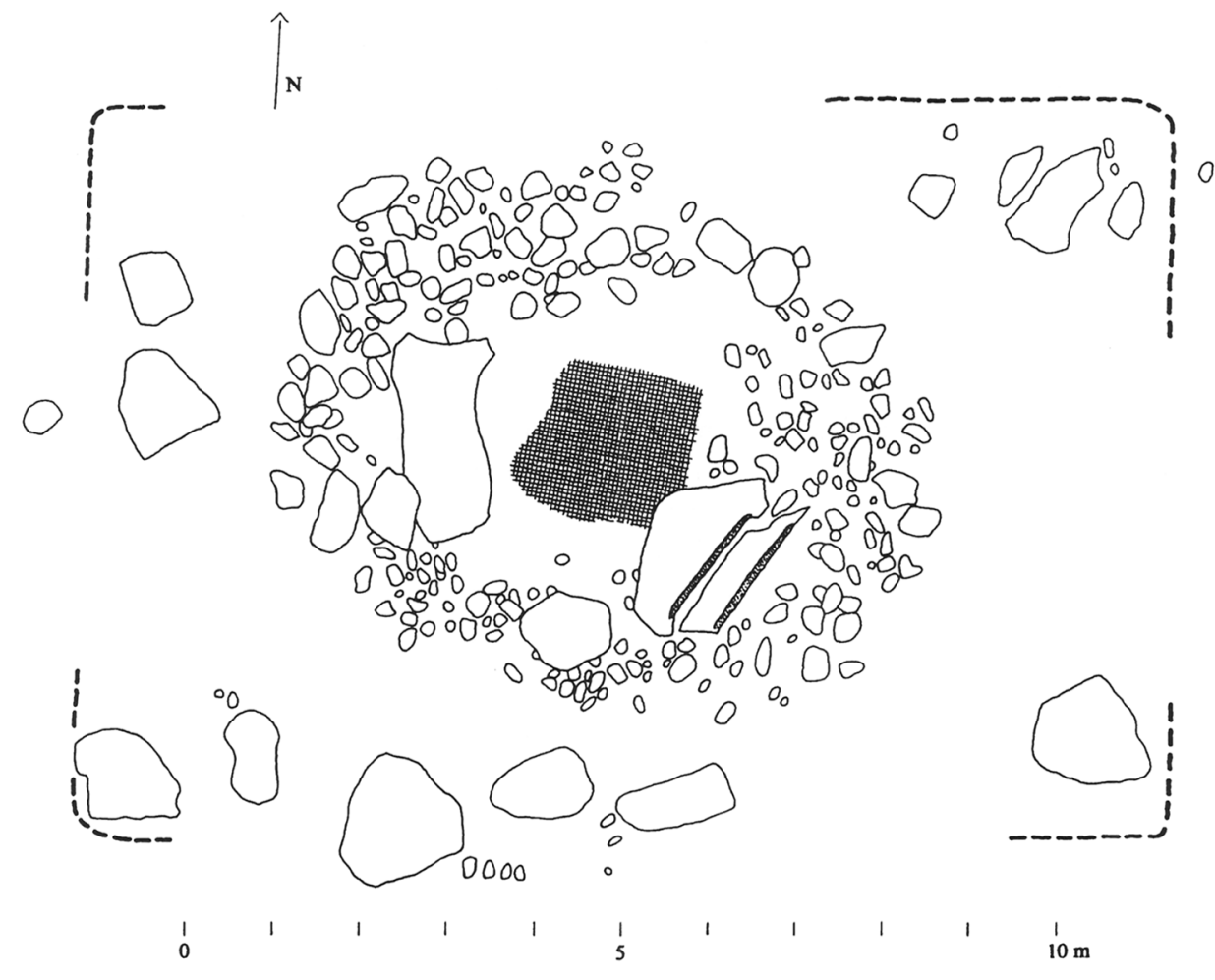

Fig. 1. Forenklet plantegning af langdyssen ved Trekroner i Hareskoven, Sjælland. Rester af randstenskæden angiver form og størrelse. Stenpakningen omkring kammeret ses, samt en større sten, der må være den kløvede dæksten. Den bevarede bundbrolægning er angivet med skravering. Tegning: K. Krogh og F. Kaul.

Simplified plan of the long mound with dolmen at Trekroner in Hareskov wood, Zealand. Its shape and size are indicated by the remains of the kerb. The stone packing around the chamber is visible, and also a large stone, which must be the remains of the capstone. Surviving floor cobbling is shown shaded.

randstenene viser, at der har været tørmure mellem disse. Der var næsten ingen egentlig højmasse til stede, og også kammeret, der befinder sig centralt $i$ dyssen, var særdeles medtaget. Det mest markante er kammerets omgivende stenpakning, som er nogenlunde cirkulær med hovedstore og noget større sten, der rager indtil 0,6 m op over det omgivende terræn. Af kammeret selv ligger der på og indenfor stenpakningen tre større og flere mindre fragmenter af en stor sten af rødlig granit, antagelig dele af dækstenen. Af urørte kammervægge fandtes blot et par partier tørmur, det bedst bevarede i 5-6 skifter med en højde af ca. $0,5 \mathrm{~m}$.

Til trods for at denne megalitgrav er temmelig ødelagt, så viste det sig, at kammerets bundlag med dets knogler var velbevaret. Dyssen er jo ikke nedpløjet, men er blot blevet delvis røvet for sten. Grunden til at knoglerne lå velbevarede kan være, at de delvis var dækket af nedskredne tørmursfliser. Knoglelaget målte ca. 1,35x1,35 m og dets tykkelse var op til 0,15 m (fig. 2). Af gravgodset fandtes blot et mindre lerkarskår af neolitisk karakter. Omkring knoglerne var jorden næsten sort, fedtet og let klæbrig, antagelig de sidste rester af lige- 
Fig. 2. Knoglelaget i Trekroner-dyssen, set mod NØ. I baggrunden til højre ses en bevaret stabel tørmursfliser. Foto: F. Kaul.

The bone layer in the Trekroner dolmen, looking NE. Behind on the right is seen a surviving heap of drystone flags.

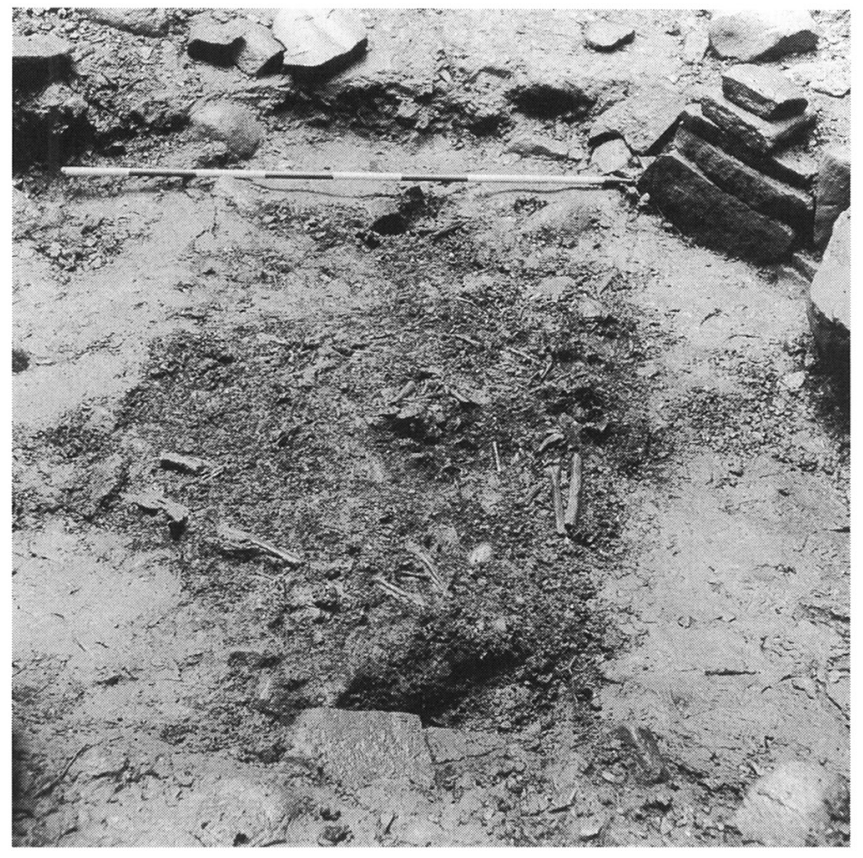

nes bløddele, såkaldt ligfedt, også konstateret i andre megalitgrave (Ebbesen 1975 s. 325; Bennike 1985 s. 469; Gräslund 1989 s. 72-73). Næsten ingen skeletdele lå i organisk orden; to albueben og et spoleben fandtes dog sammen, og det meste af halshvirvelsøjlens knogler fra en enkelt person fandtes tæet ved hinanden.

Knoglelaget hvilede på et ca. 0,10 m tykt lag af knust flint, og umiddelbart herunder fandtes en omhyggeligt og tæet lagt brolægning $\mathrm{i}$ ét lag af håndstore, rundede sten af ensartet størrelse (3). Stenene lå direkte på undergrundens gule sand. Brolægningen er kvadratisk med målene 1,75x1,75 m og må angive kammerets form og indre dimensioner (fig. 3).

Analysen af knoglerne (4) viser, at mindst ti individer er repræsenteret: en kvinde, en mand, tre voksne hvis køn ikke kan bestemmes, den ene et ret ungt individ, den anden ældre, samt ikke mindre end fem børn (3 år, 4 år, 5 år, 6 år og 13 år). Hvad der er værd at bemærke er, at hvert enkelt individ ingenlunde er fuldt til stede; flere af de døde er faktisk kun repræsenteret ved nogle fă knogler. Dette gælder i særdeleshed børnene, som først og fremmest er repræsenteret ved deres underkæber. Blandt de voksne fandtes også to større brudstykker af underkæber. Til gengæld fandtes der kun forholdsvis små og fă brudstykker af kranierne selv, ligesom de store og lange rørknogler kun er meget sparsomt repræsenteret; der er slet ikke nok dele af arme og ben til de ti døde. De mindre knogler, som f.eks. fod- og håndknogler er bedre repræsenteret.

Af sygelige forandringer konstateredes blot gigtforandringer med sammenvoksning af to halshvirvler. Udover menneskeknogler forekom også enkelte dyreknogler, herunder en del af en hjortetak, antagelig rådyr. 


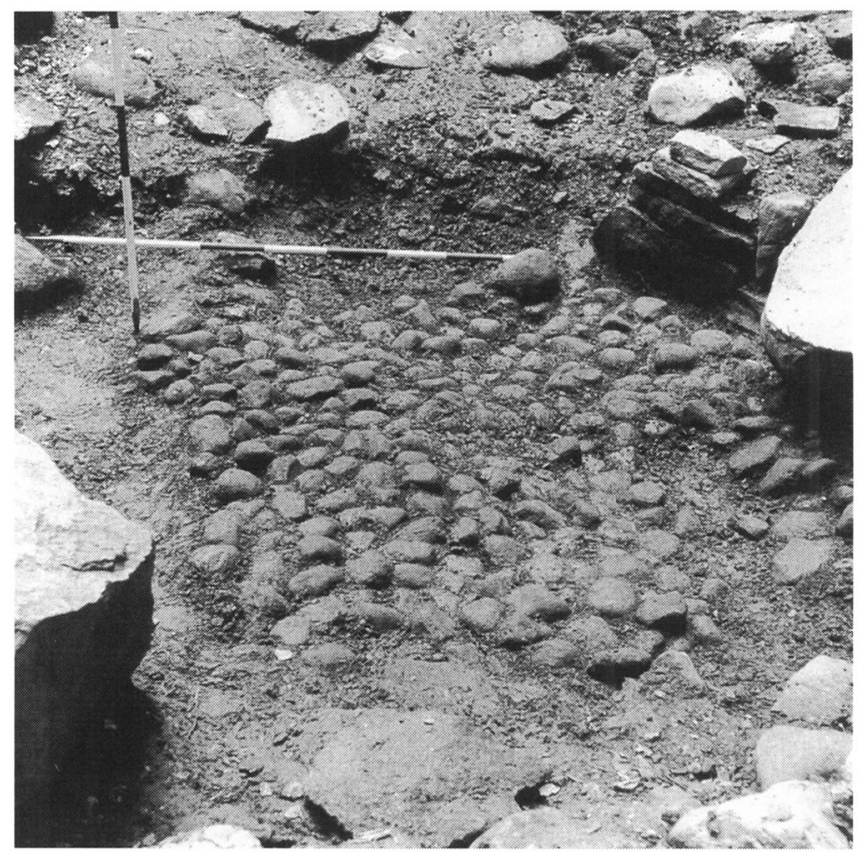

Fig. 3. Bundbrolægningen under knoglelag og lag af knust flint i Trekroner-dyssen, der angiver kammerets form og dimensioner. Set $\bmod N \varnothing$. Foto: F. Kaul.

The floor cobbling under the bone layer and shattered flint, indicating the shape and size of the chamber.

Der fandtes som nævnt ingen daterende oldsager sammen med knoglerne. En C14-analyse af ben fra knoglelaget gav dateringen $4500 \pm 55 \mathrm{BP}$, calibreret ca. $3280 \pm 120$ f.Kr. (5). Denne datering er i god overensstemmelse med de forholdsvis fă C14-dateringer, der foreligger tilknyttet opførelsen af de nordiske dysser og jættestuer (Nielsen 1984 s. 381 \& 385-86; Blomqvist 1989 s. 107110). Hvis man tør benytte en (enkelt!) C14-datering snævert i denne periode, hvor calibreringsfluktationerne er store, så befinder dateringen af knoglerne fra Trekroner sig sammen med de seneste dateringer for opførelsen af dysser og jættestuer; udfra Trekroner-dyssekammerets form og størrelse (større, kvadratisk dysse) hører den typologisk set til blandt de senere dysser. Det er således ikke urimeligt at antage, at de knogler som fandtes i Trekroner-dyssen tilhører en tid kort efter dens opførelse, at det således er dens primære begravelser vi har udgravet. Et dyssekammer af tilsvarende form udgravet af denne artikels forfatter på Onsved Mark i Horns Herred kan udfra keramikken placeres på overgangen mellem tidligneolitikum og mellemneolitikum (Kaul 1988).

Der er ingen tvivl om, at en del knogler mangler i dyssen ved Trekroner; der er alt for fă af de store, lange knogler og alt for fă kraniedele i forhold til underkæberne. Pia Bennike, der indgående har beskæftiget sig med menneskeknoglerne i bl.a. jættestuen Hulbjerg på Langeland, fremhæver, at en underrepræsentation af kraniedele kan skyldes bevaringsmæssige forhold: at et hult kranium let vil kunne knuses og forvitre under de forhold, som findes i en megalitgrav, mens det er mindre sandsynligt, at underkæberne med deres kompakte form ville forvitre i samme grad som kranieknoglerne (Bennike 1985 s. 471). Imidlertid var bevaringsforholdene i Trekronerdyssen perfekte, hvad bl.a. tilstede- 
værelsen af en stykke forkalket skjoldbrusk og et brystben viser, ligesom de forholdsvis mange små knogler fra hånd og fod var særdeles velbevarede.

At visse knogler i en megalitgrav mangler, kunne skyldes at man som led i langvarige begravelsesritualer har begravet de døde sekundært, d.v.s. som knoglebunker eller enkeltknogler efter at kødet var bortrådnet andetsteds. Men da der er forholdsvis mange af de små hånd- og fodknogler til stede, er dette næppe sandsynligt, da netop disse knoglegrupper ikke vil forventes at blive påagtet i så høj grad i forbindelse med en sekundær gravlægning. Desuden antyder tilstedeværelsen af ligfedt, at de døde i Trekronerdyssen er gravlagt med deres bløddele (Ebbesen 1975 s. 325). Knogler må således være fjernet fra gravkammeret. Det kan desværre ikke helt udelukkes, at en sådan fjernelse af karakteristiske knoglegrupper har fundet sted i nyere tid, da dyssens sten blev kløvet, udfra kløvesporene antagelig i 1500-1700 årene (Kaul \& Krogh 1990). Det kan dog fremhæves, at det kompakte knoglelag i dets ligfedt, som var velafgrænset, ikke virkede forstyrret. Laget var, som nævnt ovenfor, delvis dækket af tørmursfliser; der fandtes ingen recente eller nyere tids genstande i forbindelse med knoglelaget, mens dette var tilfældet ovenover de dækkende fliser. Det vil således være rimeligt at antage, at knoglerne repræsenterer en faktisk forhistorisk situation, og at man i neolitikum har fjernet visse karakteristiske knogler til rituelt brug. Der kunne naturligvis blot være tale om en "praktisk" udrømning, men det meget selektive udvalg af knogler, især hvad angår børnene, tyder på et bevidst valg. Som vi skal se nedenfor er der mange vidnesbyrd, der viser, at man har udført ritualer med bestemte knoglekategorier i megalittidens Europa.

\section{Jordehøj, Møn}

I efteråret 1988 undersøgte Skov- og Naturstyrelsen og Nationalmuseet i fællesskab højmassen omkring det velbevarede jættestuekammer i Jordehøj på Møn (6). En delvis nedskreden dæksten gjorde det nødvendigt at restaurere kammeret. For at kunne sætte dækstenen på plads og rette dens bæresten op var det nødvendigt at føre en grøft fra højsiden ind over kammeret, og herved blev det muligt at gøre iagttagelser angående jættestuehøjens opbygning (Hansen 1990). Resultaterne var særdeles interessante. Det viste sig bl.a., at kammeret var dækket af en omhyggeligt opbygget pakning af flade sten lagt i "mørtel" af knust ubrændt kalk, og at der i denne mørtel var afløbskanaler, som mundede ud ved kammerets hjørne(r). Langs bærestenenes bund løb en lille drængrøft fyldt med knust flint (resultaterne iøvrigt er fremlagt i Kaul 1989 og Hansen 1993 s. 60 ff).

På dette sted skal imidlertid fremlægges et fund øverst i højen. Ved undersøgelsen af den nævnte grøft, som vinkelret førtes op til og over kammeret fra dets bagside, konstateredes et mindre antal fyldskifter (fig. 4). Det ene af fyldskifterne er af særlig interesse. Det er et stolpehul placeret øverst i højen (fig. 5), og dets bund lå 1,08 m under højens nuværende overflade. Stolpehullet adskilte sig fra den omgivende højfyld af næsten rent ler ved at være knapt så leret, med en brunlig, muldspættet fyld.

I den nedre, smalle del af stolpehullet fandtes under et par mindre sten menneskeknogler uden organisk orden (fig. 6). I den øverste del af en kraniekalot (issebenet) lå som i en skål følgende knogler: Del af pandenben med øjenbrynsbue (kan høre til "skålen”), flere stykker af bækkenknogler, venstre mellem- 


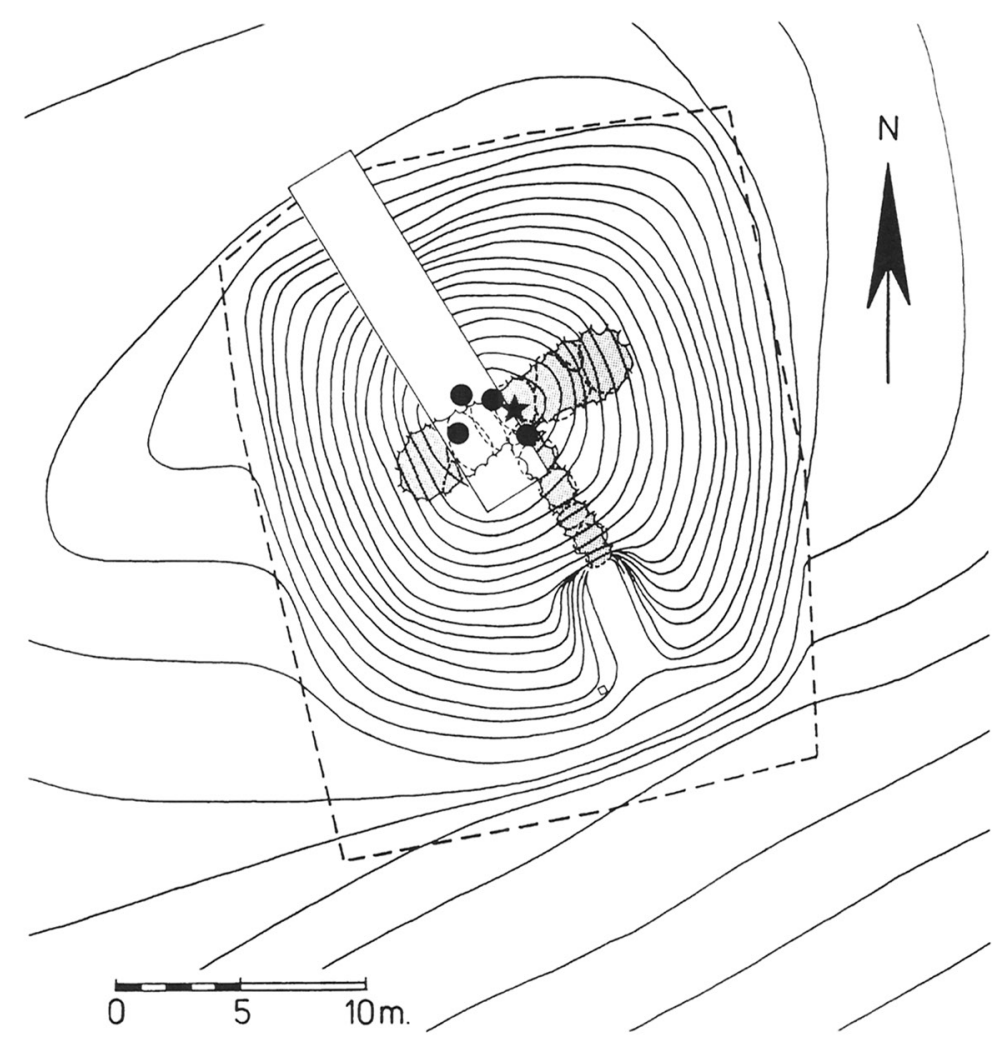

Fig. 4. Plantegning med koter af jættestuen Jordehøj, Møn. Hver kurve markerer $25 \mathrm{~cm}$. Udgravningsgrøften indover kammeret ses markeret og fyldskifter i den primære højs overflade er angivet. Stolpehullet med sit bemærkelsesværdige indhold af menneskeknogler er vist med en stjerne. Som det ses, befinder det sig nøjagtigt midt i højen på dens højeste sted. Tegning: P.E. Skovgård.

Plan of the passage grave, "Jordehøj" on Møn, contour interval $25 \mathrm{~cm}$. The excavation trench exposing the chamber is shown, with structures in the surface of the primary mound marked. The posthole containing human skeletal material is indicated by a star. It can be seen to be at the exact centre of the mound at its highest point.

håndsknogle fra pegefingeren (2. metacarpus), et ribbensfragment og tre dyreknogler (fig. 7). Det er værd at bemærke, at selvom store dele af kraniet er til stede, så er der ingen underkæbe eller dele heraf. Udfra de sammenvoksede kraniesømme (sagitalsuturer) er der tale om et voksent individ (adultus), antagelig en mand. Fingerknoglen er dog spinkel og måske fra en kvinde, således at knoglerne muligvis repræsenterer to individer (7).

Netop stolpehullet med knoglenedlæggelsen befandt sig præcist på højens højeste sted. Det er rimeligt at opfatte den nederste smalle del og det tilsvarende smalle muldede parti højere oppe, som spor af en ca. 0,1 m tyk stolpe, banket lidt ned under selve stolpehullets bund. Det er i denne lange og smalle del af stolpehullet, at knoglerne befandt sig. Man kan bedst forstå knoglernes placering her, hvis man antager, at denne nedre del er skabt ved en nedbankning af en smal stolpe, som på et tidspunkt er blevet trukket op, hvorefter knoglerne er placeret og dækket til af de mindre sten. En sådan stolpe (eller lille totempæl, 


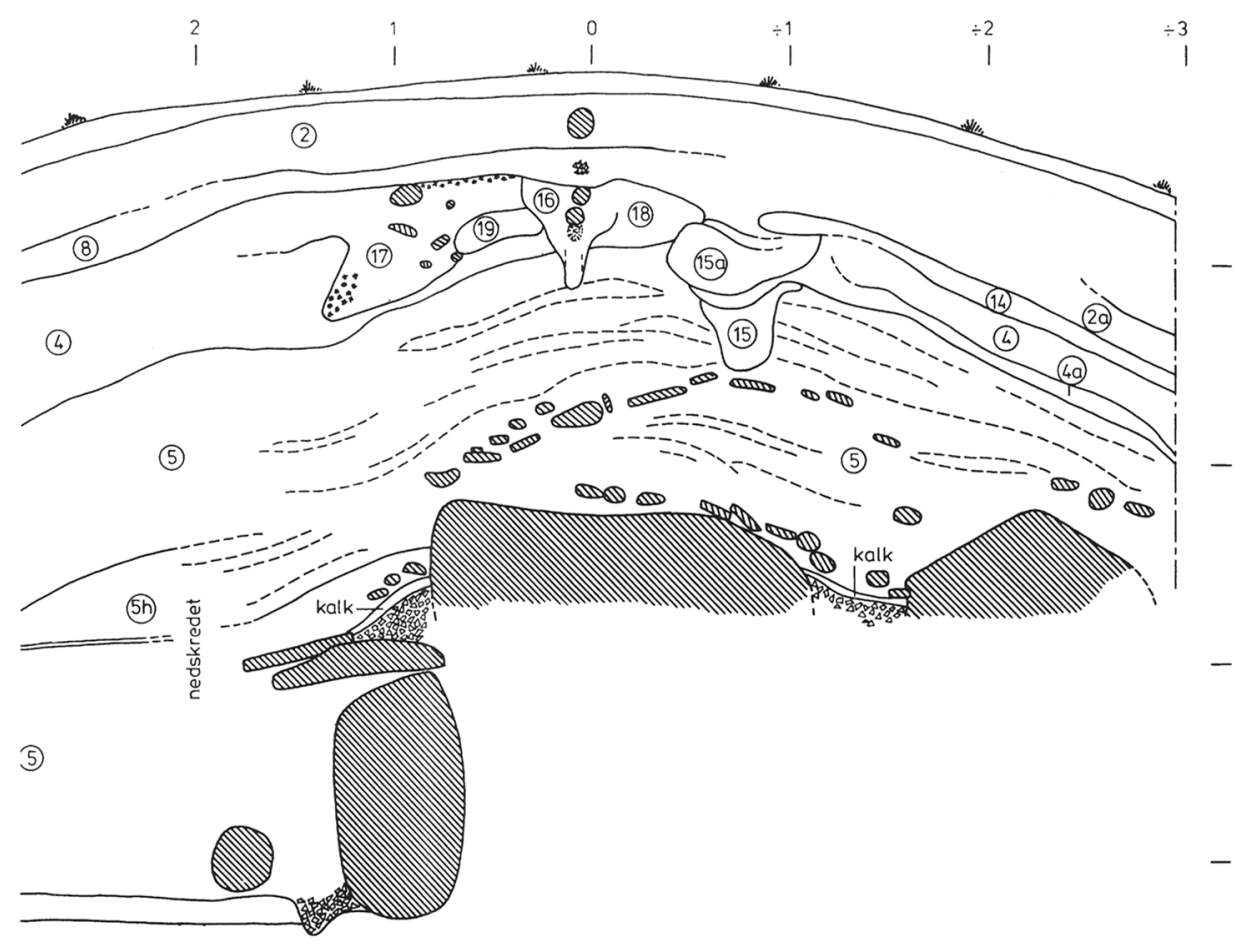

Fig. 5. Jordehøj; del af profilen i udgravningsgrøftens østlige side, hvor den forløber op over jættestuens kammer. Nederst til venstre ses den gamle jordoverflade, og den flintfyldte drængrøft ses gravet ned igennem dette lag og en smule ned i undergrunden. Mellem og over kammerets dæksten ses den komplicerede pakning bestående af knust flint, kalk, et stenlag, lerlag, og herover et øvre stentæppe. De to stolpehuller ved højens højeste punkt (lag 16, 18 og 15) synes dækket af den senere højudvidelse. Det var i stolpehullet (lag 16) under de dér angivne sten, at den interessante samling menneskeknogler fremkom. Tegning: P.E. Skovgård.

"Jordehøj", part of section on east side of trench, passing over passage grave. Lower left is seen the old soil with a drain filled with flint dug through it and going slightly into the natural. Between and above the capstones is seen a complex packing of crushed flint, chalk, stones, clay, and uppermost an upper cobbling. The two postholes at the highest point of the mound (contexts 16,18, and 15) appear to be sealed by subsequent mound enlargement. The interesting group of human bones was found in context 16 underneath the stones indicated.

om man vil?) kan have markeret højens midtpunkt eller højeste sted og have tjent rituelle formål. Det kan ikke udelukkes, at en stolpe igen er sat i hullet efter knoglerne var blevet placeret.

Da knoglerne ikke lå i organisk orden, råder der ingen tvivl om, at kødet må have været bortrådnet før de nedlagdes. Knoglerne i stolpehullet på toppen af Jordehøj er således et interessant vidnesbyrd om det neolitiske menneskes rituelle omgang med menneskeknogler.

Der fandtes ingen genstande tilknyttet denne knoglenedlæggelse. Fingerknoglen er netop blevet underkastet en C14-tandemaccelaratoranalyse på Uppsala Universitet, som har givet dateringen $4050 \pm 100 \mathrm{BP}$, hvad der calibreret giver dateringen 2580 f.Kr. eller med én standardafvigelse 2870-2470 f.Kr. (8). Selvom der kun er tale om en enkelt Cl4-datering, så er det dog rimeligt at placere disse knogler i enkeltgravstid, da dateringen ligger meget tæt ved midten af enkeltgravskulturen, således som den er bestemt gennem en lang række 


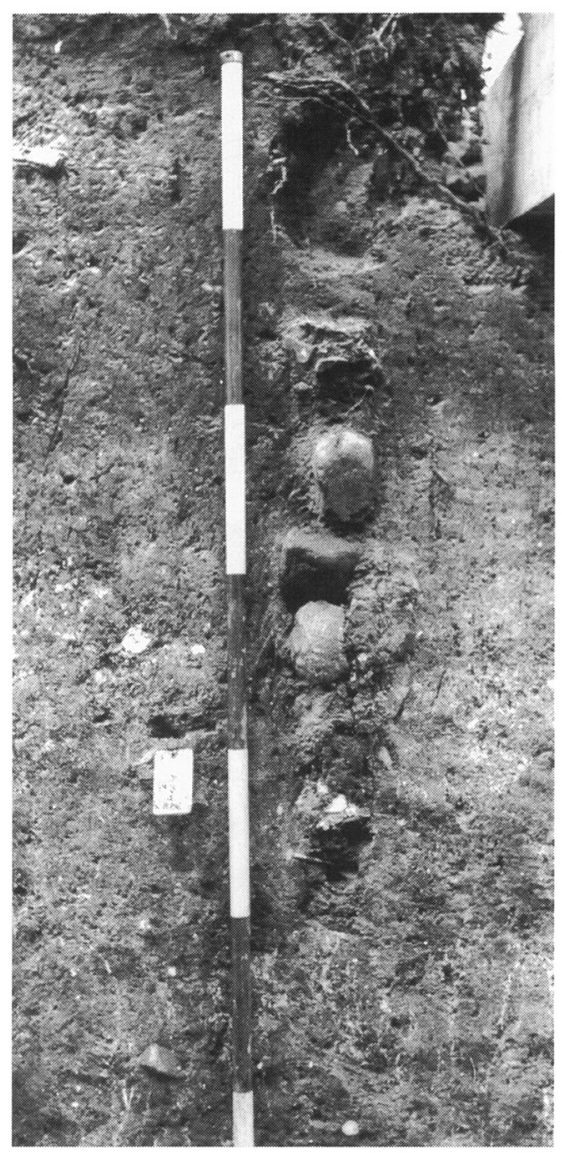

Fig. 6. Stolpehullet med knogler fra Jordehøj, som det fremtrådte i østprofilen. Kraniekalotten står lidt skråt i profilet, dækket af en mindre, lidt firkantet sten, og derover en rundagtig sten. Den centrale del af stolpehullet står tydeligt, mens den bredere del fremtræder mere utydeligt i forhold til højens omgivende ler. Foto: F. Kaul.

The posthole containing skeletal material from "Jordehøj" as it appeared in the east section. The top of the skull is sloping, overlain by a small, somewhat rectangular stone with above it a rounder stone. The central part of the posthole is clear, but the wider part less clear against the surrounding clay of the mound.

andre Cl4-dateringer. Det vil være vanskeligt at argumentere for en datering til mellemneolitikum eller senneolitikum. Det skal dog ingenlunde udelukkes, at der kan være tale om en nedlæggelse i senneolitikum af ældre knogler fra enkeltgravskultur hentet i eller udrømmet fra jættestuens kammer.

På et tidspunkt er højen over Jordehøj blevet gjort ca. $\frac{1}{2}-1 \mathrm{~m}$ højere, hvorved bl.a. den oprindelige pyntebrolægning på dens sider blev dækket. En C14-analyse af trækul (eg) fundet lige under denne højudvidelse giver dateringen 3690 $\pm 85 \mathrm{BP}$, hvad der calibreret giver dateringen 2130-2045 f.Kr. eller med en standardafvigelse 2200-1970 f.Kr.(9). Trækullet kan repræsentere en afbrænding af vegetation på højen forud for dens udvidelse. Stolpehullet med knoglenedlæggelsen kunne ikke med sikkerhed følges op i højudvidelsen. Afstanden mellem de to C14-dateringer (ca. 500 år) er efter alt at dømme for stor til direkte at knytte knoglerne til højudvidelsen. Imidlertid foreligger den mulighed, at der er tale om knogler fra enkeltgravskultur, som senere er benyttet til den rituelle nedlæggelse i senneolitikum, og at denne knoglenedlæggelse i forbindelse med en stolpe sat på toppen af højen på en eller anden måde har markeret denne udvidelse. 


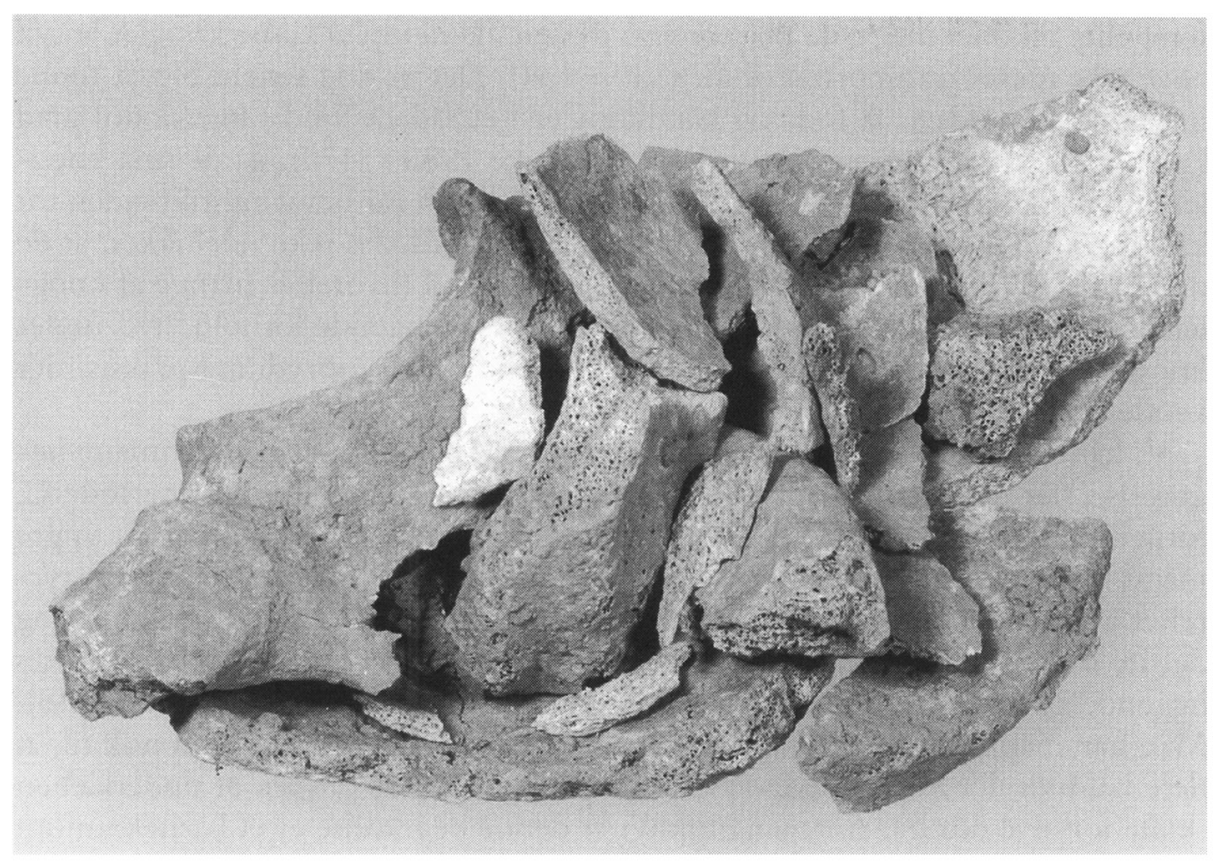

Fig. 7. Konstrueret foto af knoglerne liggende i kraniekalotten fra stolpehullet øverst i Jordehøj, Møn. Foto: Kit Weiss.

Reconstructed photograph of the bones lying in the top of the skull in the posthole at the top of "Jordehøj", Møn.

\section{Fund fra tragtbægerkulturen, der afspejler ritualer med menneskeknogler}

\section{Danmark og Skandinavien}

Ligesom ved Trekronerdyssen er det i nogle få megalitgrave iagttaget, at visse knogler mangler, antydende at disse har været benyttet i en eller anden særlig sammenhæng (1). Imidlertid er der på det seneste sat spørgsmålstegn ved om visse af fundene virkelig afspejler ritualer med udvalgte knogler fra menneskeskelettet (Bennike 1985). Det er klart, at man i hvert enkelt tilfælde bør vurdere om andre årsager kan forårsage en skæv fordeling af de forskellige knoglekategorier.

Et fund af et knoglelag fra kammeret i dyssen Klokkehøj ved Bøjden på Sydfyn (Thorsen 1981) kunne afspejle komplicerede begravelsesskikke og rituel brug af menneskeknogler i tragtbægerkulturen. Udfra C14-dateringer og lerkarskår skal dette sekundære gravlag dateres til tragtbægerkulturens senere del. Her fandtes knogler af mindst 19 individer som oftest uden organisk orden; hvert individ er kun repræsenteret ved få knogler. Især kan fremhæves en tydelig underrepræsentation af de mindre knogler som fod- og håndknogler. Dette forhold tolkes af udgraveren således, at de døde allerede var (næsten helt) skelet- 
teret eller afkødet inden de placeredes i dyssen, da netop sådanne knogler let vil blive tabt under transporten (ibid. s. 133-134). Det er dog senere blevet fremhævet, at forholdsvis få fod- og håndknogler $\mathrm{i}$ et sådant fund i lige så høj grad kan afspejle bevaringsmæssige forhold (Bennike 1985 s. 470), da de små knogler lettere kan gå til grunde end de kraftigere. Faktisk var bevaringstilstanden for knoglerne i Klokkehøj ingenlunde ideel. Det kan således ikke udelukkes, at de døde i denne dysse er blevet begravet i deres helhed (hvorefter mange af knoglerne er gået til); og at de rodede og ikke sammenhængende forhold, hvorunder knoglerne blev påtruffet, blot afspejler den sædvanlige oprydningspraksis, der kendes fra vore dysser og jættestuer.

Vi kan imidlertid næppe komme udenom, at Klokkehøjdyssens primære begravelse, der udfra gravkeramikken kan dateres til tidligneolitikums periode C, fortæller om rituel brug af menneskeknogler. Denne var et skelet af en yngre mand liggende i udstrakt rygleje. Selvom der kunne konstateres senere forstyrrelser af denne begravelse, så syntes hovedenden urørt. Det meste af kraniet og de fire øverste halshvirvler manglede, mens to halvdele af underkæben fandtes liggende på hver sin side af de resterende halshvirvler (Thorsen 1981 s. 118). Man har åbenbart fjernet kraniet, mens der stadig var sener eller kød nok til, at flere halshvirvler fulgte med, og man har tilsyneladende ønsket, at underkæben skulle forblive tilbage. Antagelig tilknyttet denne begravelse er et barnekranium af et 5-årigt barn med underkæbe. Bevaringstilstanden var dårlig, men det kan på ingen måde udelukkes, at kraniet var, hvad der gravlagdes af barnet (måske i stedet for kraniet til den voksne mand!?).

I to kamre $i$ en langdysse ved Grofte i Sydsjælland, der ikke synes at have været benyttet siden tidligneolitisk tid (Ebbesen 1990 s. 66-68), lå knoglerne af henholdsvis et og to individer i uorden, og mange knogler manglede (Bennike 1990 s. 73). Blandt knoglerne var der ikke en eneste fod-, håndknogler, eller ribben. Dette kunne ved første øjekast antyde, at de afdøde var skeletteret før den endelige gravlæggelse, men langt mere sandsynligt er det, at det simpelthen er bevaringsmæssige forhold, som spiller ind. Mange knogler viste spor af musegnav, og det er forståeligt, at det er de mindre knogler, som det er lykkedes de små gnavere fuldstændig at fortære (ibid.). At knoglerne ikke lå i anatomisk orden kan også skyldes dyreaktivitet (ræve). Det så dog ud til, at de større lemmeknogler i det ene kammer var samlet i midten. Da der ikke konstateredes spor af nogen "hel" begravelse, som denne oprydning eller ordning af knogler skulle skabe plads for, er det måske ikke urimeligt at antage, at de efterlevende er vendt tilbage til kammeret for at ordne knoglerne.

Et sikrere tidligneolitisk eksempel på ritualer omkring menneskeknogler stammer fra undersøgelsen af en overpløjet runddyse ved Fakkemose på det sydlige Langeland (Skaarup 1985 s. 206-208 \& 355). Lige indenfor randstenskæden fandtes en gravgrube rummende ligene af to voksne individer anbragt i ekstrem hockerstilling ryg mod ryg og med hovederne i vest. En nærmere undersøgelse af skeletterne viste, at det var (delvis) skeletterede lig man havde begravet, og at de bortset fra underekstremitetsknoglerne var anbragt i den snævre grube i nogenlunde korrekt anatomisk sammenhæng. En lårbensknogle var på det ene skelet anbragt således, at kugleledet lå på knæleddets plads! Stratigrafisk må graven være ældre end eller evt. næsten samtidig med den overlejrende rundddys- 
Fig. 8. Den trearmede grube under jættestuen Carlshögen i Skåne. Bemærk kraniet $\mathrm{i}$ den ene grubearm og øvrige menneskeknogler i de andre grubearme. (Efter Strömberg 1971).

The trefoil pit under the passage grave "Carlshögen" in Scania. Note the skull in one of the arms of the pit and the human bones in the other arms (after Strømberg 1971).

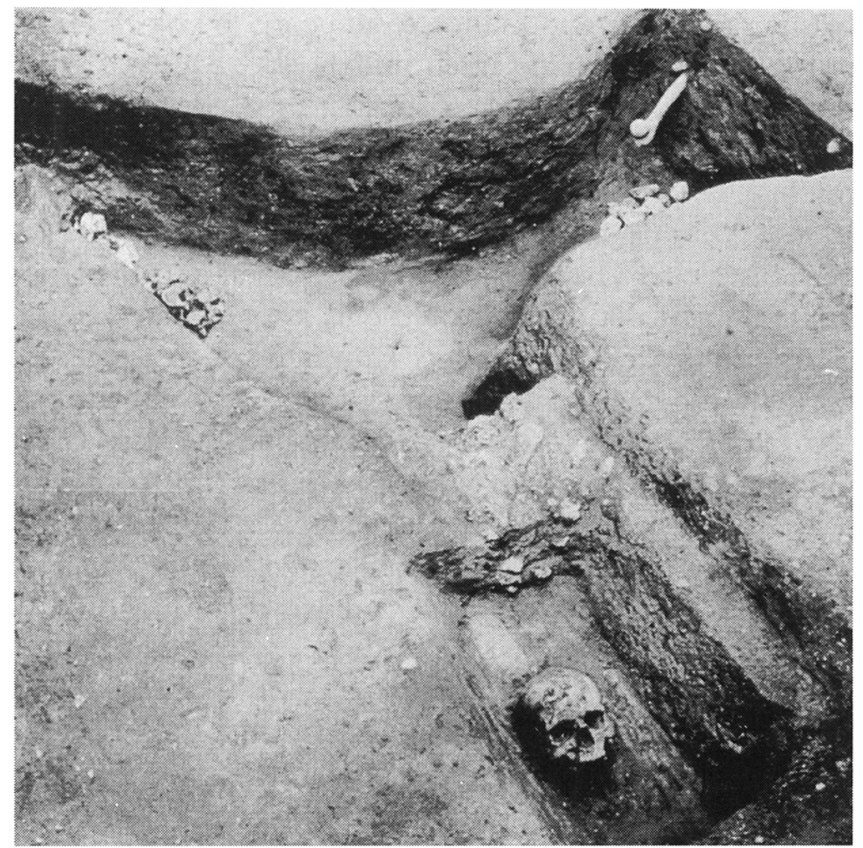

se. Graven kan formodentlig tilknyttes en ringgrøft ligeledes tidligere end selve dyssen, hvad der også kan gælde et isoleret menneskekranium, der blev fundet $\mathrm{i}$ en lille nedgravning vest for dobbeltgraven. Her må en vis skelettering således være foregået før den endelige begravelse.

Også skeletmaterialet fra langhøjen Skibshøj i Sjørup Plantage i Nordjylland fortæller om den tidligneolitiske tragtbægerkulturs gravskik og brug af udvalgte skeletdele. I det ikke-megalitiske kammer lå skeletterne af en voksen og fire børn, de tre ganske små. De lå i udstrakt rygleje side om side, var hele og komplette og er i sig selv et fremragende vidnesbyrd om, at man i tragtbægerkulturen begravede hele og sammenhængende lig (Jørgensen 1977 (a) s. 7 ff.). Imidlertid lå der på brystet af den ene af de døde en ekstra underkæbe, der derved fortæller om en særlig omgang med udvalgte dele af menneskeskelettet (10). Vi kan selvsagt ikke vide om den ekstra underkæbe blev båret som en amulet eller et minde om en nærtstående af den begravede i Skibshøjgraven, eller om der er tale om en nedlæggelse af denne ekstra underkæbe i forbindelse med særlige begravelsesskikke.

De bemærkelsesværdige knoglefund under gulvlaget i jættestuen Carlshögen ved Hagestad i det sydøstlige Skåne må regnes som et klart eksempel på rituel omgang med menneskeknogler i mellemneolitisk tragtbægerkultur (Strömberg 1971). Da Carlshögens urørte jættestuekammer undersøgtes i 1960 'erne, fandtes under dets kraftige primære gulvlag (ibid. s. 40 ff., fig. 23-30 \& 36-38) et besynderligt anlæg - en "trearmet" grube - (fig. 8). I grubens ene arm fandtes knogler af tre individer, et barn, et ungt menneske og en voksen, bl.a. en underkæbe, et par ryghvirvler, et ribben, en overarm, to lårben og et par fingerknogler. I den anden grubearm lå en bunke knogler, udelukkende ryg- og 
halshvirvler, af fire individer, to unge og to voksne. I den tredje arm lå et kranium af en voksen mand uden underkæbe. I hver af grubens arme lå desuden en bunke knust flint og flintafslag. Det er således kun en meget ringe del af hvert repræsenteret individ, som er nedlagt her. En C14-analyse af knogler i den førstnævnte grubearm giver en datering på ca. 3000 f.Kr. calibreret (ibid. s. 59). Meget tyder på, at denne særlige grube er gravet og fyldt, før kammeret blev taget $\mathrm{i}$ brug eller i hvert fald i en tidlig del af dets brugsperiode. Det kan ikke helt udelukkes, at dette anlæg med dets knoglenedlæggelser kunne afspejle en slags udrømning eller oprydning i kammeret, men selve dets ejendommelige form og de udvalgte knogler anskueliggør, at vi står overfor en rituel nedlæggelse (Strömberg 1971 s. 331-334), antagelig en slags indvielsesoffer i forbindelse med jættestuens opførelse. En ganske lignende grube fandtes også under et jættestuekammer ved Ingelstorp, ligeledes i det sydlige Skåne, og her kunne det med fuld sikkerhed klarlægges, at nedlæggelsen af knogler fandt sted før kammerets gulvlag af knust flint og ler placeredes, formodentlig i tilknytning til bygningen af kammeret (ibid. s. 332). Desværre var knoglernes bevaringstilstand her så ringe, at en nærmere bestemmelse var umulig.

I jættestuen Ramshög, Sydskåne, fandtes en mindre, oval grube, forseglet under kammergulvet, så den må være anlagt før kammeret blev taget i brug. I gruben lå både brændte og ubrændte menneskeknogler. De ubrændte kunne bestemmes, og de stammer fra mindst to individer, en ung og en voksen mand, men omfatter kun få knogler fra hver (Strömberg 1971 s. 100). Altså igen en forsætlig nedlæggelse af enkeltknogler. Da knoglerne må være nedlagt afkødet, og da kammeret med dets gulvlag endnu ikke var taget $\mathrm{i}$ brug ved deres nedlæggelse, er det rimeligt at antage, at knoglerne hentedes andetstedsfra i afkødet tilstand til brug for særlige ritualer i forbindelse med jættestuens opførelse. En C-14 analyse af de ubrændte knogler har ydet en datering, der calibreret ligger omkring 3200-3300 f.Kr., hvad der svarer til de fă øvrige dateringer knyttet til opførelsen og den første brug af vore jættestuer og til de senest daterede af dysserne (jævnfør Nielsen 1984). Også under selve højmassen og delvis under den ene af kammerets bæresten fremkom en grube med et indhold af enkeltknogler af ganske samme art (Strömberg 1971 s. 105), hvor tolkningen må være den samme. Tilsvarende deponeringer af kraniefragmenter, hvirvler, armstykker m.m. fra mindst tre individer fandtes indlejret i lerpakningen omkring kammeret sammen med en dyreknogle og affaldsprodukter fra fremstillingen af den knuste flint anvendt som pakning bag kammerets bæresten. Disse sidstnæunte knogler må opfattes som udtryk for ritualer i forbindelse med selve bygningen af jættestuen.

De ovennævnte eksempler synes med større eller mindre sikkerhed, at kunne tilknyttes indvielsesritualer omkring megalitgrave eller en primær brug af gravene (dette gælder dog ikke det sekundære lag fra Klokkehøj). Men også fra en lidt senere del af megalitgravenes brug, en mere fremskreden del af mellemneolitikum, synes der at være vidnesbyrd om ritualer omkring menneskeknogler.

Foran området ved gangmundingen ved Ramshög fandtes udover det for megalitgrave sædvanlige offerlag tillige nogle mindre gruber, som indeholdt brændte ben, lerkarskår, en tyndbladet flintøkse m.v. (Strömberg 1971 s. 335- 
338), der daterer disse nedlæggelser til en mere fremskreden del af mellemneolitikum. Tilsvarende fund stammer fra området foran og på begge sider af indgangen ved dyssen Trollasten i det sydøstlige Skåne (Strömberg 1968 s. 119 ff \& 197 ff). Her fremkom brændte menneskeknogler sammen med brændte flintgenstande. Desuden var der to lignende bunker af menneskeknogler i henholdsvis kammer og gang, også sammen med brændte flintredskaber. De 11 fundpletter med menneskeknogler, som udfra fundmaterialet kan dateres til anden halvdel af mellemneolitisk tid, fremtrådte som små sluttede bunker. Ialt er mindst 2 individer repræsenteret i disse bunker. Disse nedlæggelser tolkes som menneskeofre, hvor man har brændt de ofrede (måske efter rituelle kannibalistiske måltider), og $\mathrm{i}$ forbindelse med ritualer har nedlagt benene sammen med de brændte flintgenstande (ibid. s. 207). En anden mulighed er, at det drejer sig om knogler og genstande, som er udrømmet fra kammeret og brændt (Kjærum 1969 s. 229). Men en sådan tolkning ændrer ikke det grundlæggende forhold, at der er tale om bevidste nedlæggelser, som må have haft en særlig kultisk og rituel betydning (Strömberg 1971 s. 337). Iøvrigt behøver disse fund ikke at afspejle egentlige menneskeofre eller kannibalisme, selvom knoglerne måske ikke har været en tur i kammeret først, men er nedlagt "direkte". Det kan blot være endnu et eksempel på særlig rituel omgang med knogler. At knoglerne oftest forekom i snæver tilknytning til ligeledes brændte flintredskaber kunne måske snarere tyde i retning af "sekundære" ritualer med knoglerne.

I et offerlag i tilknytning til en langdysse ved Hindby Mosse i Skåne er fundet grupper af brændte menneskeknogler sammen med keramik og ravperler dækket af sten og fliser. Offerlaget og knoglerne fandtes lige øst for midten af langdyssens ene langside (Burenhult 1973 \& 1981 s. 314), hvor det havde en udstrækning på mere end 10 kvadratmeter. Den tilhørende keramik synes at kunne dateres til MN I-II efter dansk kronologi. Der synes ikke at være senere forstyrrelser, og det åbenbart stendækkede fundlag af rituel karakter kan således opfattes som "rent". Der er tale om 71 mindre koncentrationer af brændt ben (med en totalvægt på 1,450 kg) lejret umiddelbart under en stenbunkes dækkende fliser. 97\% af knoglerne stammer fra menneske, kun 3\% fra dyr (okse). Ikke mindre end 94\% af de brændte menneskeknogler hører til kraniet, resten er ekstremitetsknogler, en stump af et skulderblad samt uidentificerbare knogler. Knoglerne må være forsætligt sønderdelte, for de foreligger i små fragmenter. Antallet af individer kan være omkring 10 (Gejvall i Burenhult 1973 s. 45-46). Det er vigtigt at notere sig den altdominerende overvægt af kranieknogler, der må skyldes et bevidst udvalg. Med andre ord har man her nedlagt brændte og knuste kranier som udtryk for særlige ritualer omkring denne knoglekategori. De brændte menneskeknogler tolkes af udgraveren som menneskeofre i forbindelse med bisættelser i dyssen selv, og den væentlige overvægt af kraniefragmenter tyder på rituel kannibalisme, hvor man har fortæret hjernen (Burenhult 1973 s. 48 \& 74; 1981 s. 311-314). Det kan dog ligesåvel dreje sig om særlige ritualer med knogler (her kranier) af tidligere døde, hvor kødet allerede var borte, da knoglerne brændtes og knustes.

Lignende fund af brændte menneskeknogler stammer fra området omkring indgangen til den kendte Hagebrogård-jættestue i Nordjylland, hvor de er placeret under og $\mathrm{i}$ en jord- og stenbunke lagt foran indgangen. Bunken ligger 
over det egentlige offerlag, og kan måske opfattes som en slags forsegling af dette (Jørgensen 1977 (b) s. 14 \& 180). I området foran indgangspartiet foran Vroue Hede III jættestuen fandtes små områder med brændte ben, der dog ikke kunne identificeres nærmere, så vi kan ikke vide om der faktisk er tale om menneskeknogler. Her fandtes knoglerne ovenpå en jord- og stenbunke af tilsvarende art dækkende keramik-offerlaget, og i niveau med knoglerne (men ikke i snæver kontakt) fandtes brændte flintgenstande hørende til en senere del af mellemneolitikum (ibid. s. 110 \& 180). Også i dette tilfælde tolkes knoglefundene som udtryk for mennskeofre; men som nævnt ovenfor kan man ligesåvel tolke sådanne fund som udtryk for ritualer med menneskeknogler.

Foran jættestuen Jordhøj i Østjylland fandtes ved undersøgelsen i 1960'erne en samling brændte menneskeknogler, som lagmæssigt hører sammen med udrømningen af kammeret, selvom det dog ikke er helt sikkert at knoglerne snævert kan knyttes hertil. De er indlejret i udskredet højfyld fra tiden, hvor facaden allerede har været i stærkt forfald (Kjærum 1970 s. 26 \& 53-54). At der muligvis kan være tale om udrømmede og herefter brændte knogler, udelukker dog på ingen måde, at et sådant fund kan afspejle ritualer omkring menneskeknoglerne. Der kendes fra ældre udgravninger tilsvarende forekomster af brændte menneskeknogler foran megalitgravene, hvor de i enkelte tilfælde kan være nedlagt sammen med brændte flintredskaber, først og fremmest økser (ibid. s. 53 \& Kjærum 1969 s. 228-229).

Udover egentlig brændte (kalcinerede) ben forekommer der i vore megalitgrave også let brændte ben. Forekomsten af sådanne regnes gerne som udtryk for mindre brændinger inde i kammeret, f.eks. fra fakler eller mindre bål tændt af praktiske grunde: for at kunne oplyse kammeret, eller for at rense luften. Tilknyttet det mellemneolitiske begravelseslag i jættestuen ved Kyndeløse i Nordsjælland fandtes således et ildsted, der havde brændt enkelte af menneskeknoglerne let (Thorvildsen 1939 s. 23). Kun få knogler var berørt af ilden, idet de fleste var skubbet til side, åbenbart for at give plads for ildstedet. Sådanne forhold bør dog ikke udelukke, at let brændte knogler i visse tilfælde kan opfattes som udtryk for ritualer af en eller anden art. Således har Køge Museum i efteråret 1991 ved Varpelev på Stevns undersøgt en overpløjet jættestue med kammerets indhold intakt og knoglerne velbevarede. Menneskeknoglerne fra jættestuens mellemneolitiske gravlag (ikke den tidligste del af mellemneolitikum) var som oftest let brændt, og optrådte i bunker med trækulsfarvet jord uden organisk orden; i bunkerne forekom, ligeledes ofte brændt, lerkarskår og flintgenstande, f.eks. mejsler, flækkeknive og tværpile. En plausibel tolkning af disse forhold er, at såvel knogler som en stor del af lerkarskårene og flintgenstandene, efter en let brænding placeredes i kammeret i disse bunker (11). Der kan således her være tale om et eksempel på en jættestues brug til ægte sekundære begravelser af allerede andetsteds afkødede knogler sammen med et ligeledes sekundært placeret gravgods. Iøvrigt synes de lange lemmeknogler at være underrepræsenteret i Varpelev-jættestuen, hvad der endnu engang understreger knoglernes funktion i ritualer. Måske har der været tale om en tilsvarende fundsituation i den nordsjællandske jættestue ved Gundsølille, hvor der angives fund af let brændte ben ("svedne knokkelstykker") sammen med sekundært brændte mellemneolitiske skår i en kulblandet fyld (Madsen 1896 s. 12-14). 
Ved Skov- og Naturstyrelsens megalitprojekt (6), der finder sted i samarbejde med Nationalmuseet, blev jættestuen Nissehøj ved Vellerup Sogn i Horns Herred underkastet en gennemgribende restaurering i 1992. I forbindelse hermed undersøgtes et parti foran og syd for jættestuens indgang. Der konstateredes udstrakte stenlægninger samt et offerlag indeholdende hundredevis af mellemneolitiske lerkarskår med en kompliceret stratigrafi. I forbindelse med dette offerlag fandtes fem kranier, fra en yngre voksen, et ca. 12-årigt barn, et ca. 6-årigt barn og to ubestemmelige individer, samt kæbedele, muligvis fra en underkæbe. Der fandtes også et par lemmeknogler. Da fundet ikke er færdigbearbejdet, vil vi ikke her komme nærmere ind på kraniernes stratigrafiske placering i forhold til offerlaget, men blot notere, at kranierne sandsynligvis er nedlagt senere end den mellemneolitiske keramik (12). Her ser vi således endnu et eksempel på, at kranier og underkæber adskilles i forbindelse med ritualer ved vore jættestuer. Det skal dog nævnes, at vi ikke kan udelukke, at underkæber kunne gemme sig i den ikke undersøgte del af området ved jættestuens indgang.

Selvom der således kan fremhæves en række fund fra den nordiske tragtbægerkultur, som dokumenterer særlige ritualer med menneskeknogler, foreligger der også klare vidnesbyrd, om at megalitgravenes kamre benyttedes til "almindelige" begravelser af hele lig. Dette gælder således for Hulbjerg-jottestuen på Langeland, det eneste danske jættestuefund, hvor knoglematerialet i sin helhed er blevet underkastet en tilfredsstillende analyse (1). Her tyder intet på, at der skulle være tale om begravelser af skeletdele fra lig, hvor kødet først var bortrådnet andetsteds; der er en ligelig repræsentation af de forskellige knoglekategorier fra de omkring 53 individer i jættestuen (Bennike 1985 s. 470-474; Skaarup 1985 s. 372). Dog var der lidt for fă kranier og kraniefragmenter i forhold til mange af de øvrige knogletyper og især i forhold til antallet af underkæber. Dette kan skyldes, at kranieknogler forvitrer lettere end de mere kompakte underkæber. Det er iøvrigt vigtigt at bemærke, at det ikke har været muligt at henføre dele af skeletmaterialet fra Hulbjerg-jættestuen til enten tragtbægerkultur, enkeltgravskultur eller senneolitisk kultur, hvorfor det følgelig ejheller er muligt at anslå i hvor høj grad de observerede forhold kunne være særlig karakteristiske for en af disse perioders brug af jættestuen.

Andre, fortrinsvis ældre fund, synes i høj grad at dokumentere, at hele lig placeredes i jættestuerne enten i siddende stilling med ryggen op ad kammervæggen eller i udstrakt rygleje; desuden antyder tilstedeværelsen af det såkaldte ligfedt, at begravelserne var primærbegravelser, hvor forrådnelsen fandt sted i kammeret (Strömberg 1971 s. 291; 1973 s. 90-91; Ebbesen 1975 s. 324-325; Skaarup 1985 s. 372; Gräslund 1989 s. 72-74). Også den hyppigt iagttagne tilstedeværelse af sammenhørende skeletdele i jættestuerne viser, at "der har været kød på", da de nedlagdes: sammenhørende lemmeknogler, de små knogler fra hænder og fødder, ribben og brystben liggende i anatomisk korrekt sammenhæng.

Også fra dysserne og fra andre af tidens gravtyper er der vidnesbyrd om, at hele lig placeredes i udstrakt rygleje. Dette udelukker dog ikke, at man efter begravelsen kan have fjernet visse knogler, således som forholdene i Klokkehøjdyssen eller i Trekroner-dyssen (se ovenfor) sandsynliggør.

I de fleste tilfælde, hvor en jættestues kammer med bevarede knogler er un- 


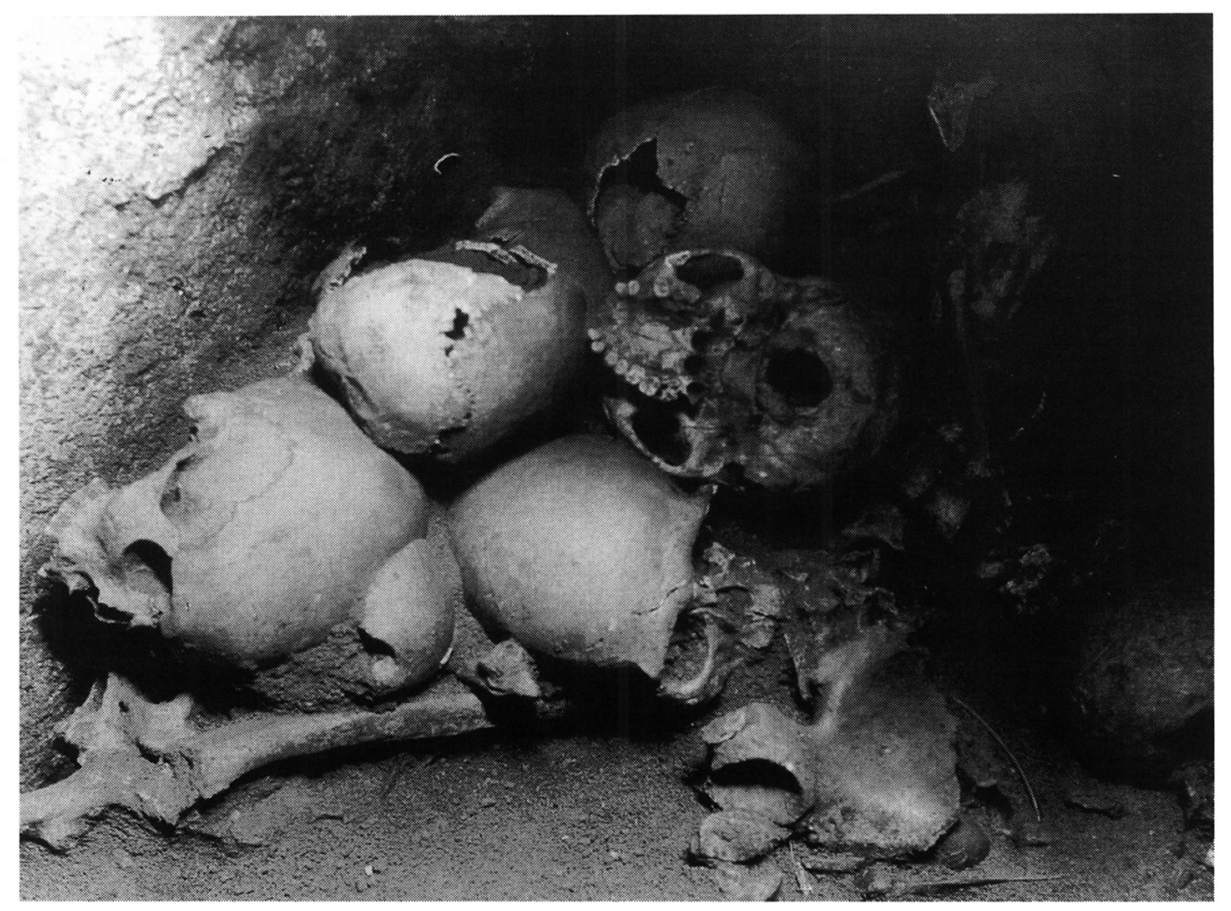

Fig. 9. Opbunkede kranier i et hjørne af jættestuen Rævehøj, Sorø Amt. I denne bunke var der 9 kranier samt andre knogler, deriblandt 4 underkæber, hvoraf dog ingen sad på plads. Foto: Hans Kjær, Nationalmuseet.

Pile of skulls in a corner of the passage grave "Rævehøj", Sorø county. This pile included 9 skulls as well as other bones, among which are 4 mandibles, which were not in articulation with any of the skulls.

dersøgt, ligger hovedparten af knoglerne dog ikke i anatomisk korrekt sammenhæng, hvad der naturligt nok har medført en vis usikkerhed omkring karakteren af den egentlige begravelse. Ved brugen af kammeret i længere tid har man skubbet knogler til side; men ofte er dette sket med en vis orden. I flere tilfælde er bestemte knoglekategorier bunket pænt op, hvad der f.eks. kan gælde kranier, lårben eller skulderblade. F.eks. lå 20 kranier sammen i et hjørne i Kyndeløse-jættestuen i Nordsjælland, og i et hjørne af jættestuekammeret i Ravehøj i Vestsjælland lå ni kranier bunket op (fig. 9). I Uggerslev-jættestuen på Fyn fandtes i kammerets vestende tre knoglebunker med et kranie anbragt på toppen af hver, mens der i den modsatte ende var en stor knoglebunke, ovenpå hvilken kranierne omhyggeligt var placeret ved siden af og ovenpå hinanden (Madsen 1900, s. 7-9 \& fig. 130; Nielsen 1981 s. 86; Midgley 1992 s. 451-454). Dette bør efter alt at dømme opfattes som oprydninger inde i kammeret af allerede begravede snarere end som placering af knogledele fra andetsteds afkødede lig. Men en sådan oprydning og omhyggelig ordning kan meget vel have omfattet ritualer (13).

Vi har set, at der indenfor den nordiske tragtbægerkultur træffes en række fund, som fortæller om ritualer med menneskeknogler, men på den anden side er der 
også klare vidnesbyrd, som viser, at de døde begravedes i megalitgravene på "normal" vis. Dette udelukker ikke, at man i forbindelse med langvarige og komplicerede begravelses- eller døderitualer har hentet bestemte knogler i gravene til brug ved ritualer andetsteds.

Et sådant "andetsteds" kan meget vel være de store rituelle grøftanlæg, der i Danmark benævnes Sarup-anlæg, og som vi her i landet nu kender mere end 22 af (Andersen 1990 (a)). Blandt den lange række af aktiviteter, som har fundet sted på disse pladser, hører også rituel omgang med menneskeknogler. På Sarup selv, Sydvestfyn, fandtes fra den ældste byggeperiode tilhørende Fuchsberg-fasen to steder i grøfterne menneskeknogler. I det ene tilfælde en underkæbe fra en voksen mellem 25 og 30 år, i det andet tilfælde hele tandsættet fra et barn i 8-10-års-alderen samt formuldede spor af kraniet (Andersen 1981 s. 70-71; 1988 s. 30-31). Selvom bevaringsforholdene for knogler på Sarup var dårlige, er det alligevel værd at notere sig, at det er underkæber og kranier, der er fundet, netop de dele af skelettet, som ved ritualerne oftest har haft bevågenhed.

I den yngre fase Sarup II, fra mellemneolitikums periode I b (Andersen 1981 s. 82), er der undersøgt et par særegne bygninger bestående af en halvbueformet grøft og nogle stolpehuller. I stolpehullerne til den ene bygning (hvor stolpehullerne danner et kvadrat) fandtes brændte menneskeknogler (Andersen 1988 s. 43-46; 1990 (b) s. 109-110), der er stammer fra ét yngre, voksent individ. Mange knogler mangler, bl.a. kraniet eller i hvert fald dele af kraniet; det er først og fremmest de lange knogler og knogler fra kroppens øvre del, som er til stede (14). Det er ikke vanskeligt at forestille sig, at der i en sådan bygning kan have været udført ritualer af en eller anden art i dette i sig selv storstilede rituelle anlæg.

Den i neolitisk forskning velkendte lokalitet Bundsø på Als i Sønderjylland kan regnes for et Sarup-anlæg med systemgrøfter af den karakteristiske art, der dateres til mellemneolitikums periode I (Andersen 1990 (a) s. 438). Også på denne lokalitet er der fundet menneskekranier og andre knogler. Ved de tyske udgravninger på pladsen for genforeningen fandtes seks kraniebrudstykker omfattende kraniekalot og pandeben tilhørende to voksne kvinder (Hoika $1987 \mathrm{~s}$. 150). På det ene kranium findes snit- eller stikspor, som ikke udelukker en voldelig død. Meget tyder på, at brudstykkerne af dette kranium ikke er nedlagt i anatomisk sammenhæng, men som kraniestykker (Asmus 1987 s. 265). Ved de senere danske udgravninger er fremkommet en kraniekalot, som fremviser slideller forarbejdningsspor langs kanten; den kan muligvis have været benyttet som en skål (Nielsen 1981 s. 104-107; se også Rydbeck 1931 s. 84-85 \& Pl. I)). Endelig foreligger fra Bundsø to upublicerede kraniekalotter fra de seneste arkæologiske undersøgelser på pladsen under ledelse af Poul Otto Nielsen, Nationalmuseet (15). Andre menneskeknogler fundet ved undersøgelser på Bundsøpladsen er dele af lårben, overarm, spoleben, albueben, lægben samt halshvirvel (Degerbøl 1939 s. 88). Det er påfaldende, at der på Bundsø er fundet kraniefragmenter fra flere individer, men ingen underkæber, hvilket taler for en rituel nedlæggelse af særligt udvalgte knogler. Da det er underkæberne, der regnes for at være mere robuste end kranierne, kan man følgelig ikke forklare forekomsten af kranier i forhold til manglen af underkæber som udtryk for forskelligartede bevaringsmuligheder. 
Lignende forhold er iagttaget på det meget lovende Sarup- anlæg ved Hygind på det vestligste Fyn (Andersen 1990). Ved en begrænset undersøgelse konstateredes på bunden af en af systemgravene, som dateres til mellemneolitikums periode II, en bunke af menneskekranier og oksekranier samt andre knogler og hjortetakker. Også her mangler underkæberne til menneskekranierne (16).

Selvom den iagttagne overrepræsentation af underkæber i megalitgrave kan forklares som udtryk for bevaringsmæssige forhold (Bennike 1985 s. 471), så er det dog fristende at anskue dette træk i sammenhæng med de manglende underkæber tilknyttet de to sidstnævnte Sarup-anlæg, Bundsø og Hygind (17). Det kan ikke udelukkes, at der er foregået sammenhørende ritualer, hvor både megalitgravene og Sarup- anlæggene har været inddraget. Hvis dette har været tilfældet, så er det mest nærliggende, at de udvalgte knogler som f.eks. kranier kan være transporteret fra megalitgravene til Sarup-anlæggene snarere end den omvendte vej. Som vi skal se nedenfor, foreligger der arkæologiske vidnesbyrd fra England, der i høj grad taler for, at noget sådant har fundet sted dér.

Iøvrigt fortæller et ligeledes nyligt undersøgt Sarup-anlæg ved Skævinge i Nordsjælland også om en snæver sammenhæng mellem megalitgravene og disse grøftanlæg: i dette anlægs grøfter, der dateres til tidligneolitikums periode C, fremkom en del tørmursfliser og afhugne flisestykker, der viser, at disse fliser, som benyttedes i megalitgravene, er tilhugget på dette sted (18). Iøvrigt er Danmark med sine rige keramikfund fra såvel Sarup-anlæg som megalitgrave netop et af de områder i Europa, hvor kommende studier vil kunne belyse det snævre samspil mellem de to anlægstyper, såvel kronologisk som strukturelt og landskabsmæssigt (Andersen 1990 (b) s. 110-111).

Også enkelte mosefund fortæller om tragtbægerkulturens ritualer med lig eller menneskeknogler. Vi skal ikke her komme ind på fund af egentlige, hele moselig (se Bennike \& Ebbesen 1987; Ebbesen 1989), men blot omtale et fund fra Myrebjerg på Langeland. Det blev tidligere dateret til yngre bronzealder (Broholm \& Fischer-Møller 1934), men placeres nu udfra en C14-datering og tilknyttet keramik i tidligneolitikums periode C eller overgangen mellem tidligog mellemneolitikum (Skaarup 1985 s. 76-77 \& s. 358; Bennike \& Ebbesen 1987 s. 101-104). Her er i den datidige sø, dækket af en stendynge, nedlagt en knoglebunke med rester af mindst fem mennesker, to mindre børn, to unge mennesker og en voksen kvinde, samt knogler af okse, făr, svin og hest, hvoraf nogle marvspaltede. Store dele af menneskekranierne lå samlet for sig. Det er muligt, at hele dette fund skal opfattes som en måltidsplads for et kultisk måltid, men det er dog ikke med sikkerhed dokumenteret, at de knuste menneskeknogler afspejler kannibalisme.

Også andre fund fra vore moser, antagelig tilknyttet tragtbægerkulturen, antyder rituelle måltider hvori kannibalisme måske kan have indgået, eller hvor kranier i særlig høj grad er blevet nedlagt (Becker 1945 s. 167-70; 1947 s. 27476; Skaarup 1985 s. 377; Ebbesen 1986 s. 32). Det gælder således et andet fund fra Føllenslev Mose end det under senneolitiske fund omtalte (se nedenfor) med rester af flere mennesker, bl.a. tre kranier og mange dyreknogler, heriblandt et par oksekranier med panden slået ind. Muligvis skal dette fund dateres til enkeltgravskultur, idet den kendte skæftede votivøkse fra Føllenslev Mose er fun- 
det tæt ved disse knogler. I Snoldelev Mose i Østsjælland skal der være fundet et meget stort antal kranier sammen med dyreknogler, lerkar og flintøkser (Becker 1947 s. 275). Det store mosekompleks ved Alvastra, Östergötland, Sverige, der måske skal opfattes som et slags "mose-Sarup-anlæg", fremviser også interessante vidnesbyrd om ritualer med menneskeknogler og kranier (Brovall 1986).

Fra en bopladsgrube ved Kornerup nær Roskilde i Midtsjælland stammer en overarmsknogle af menneske med en fure og forskellige snitmærker, men der er tillige spor af hundebid på knoglen (Brøndsted 1967 s. 268; Broholm \& Møller 1934). Lokaliteten ligger ved adgangen til et markant næs med Lejre Å på den ene side og et $s ø /$ moseområde på den anden, og det kan ikke udelukkes, at de mange mellemneolitiske gruber udgravet på stedet i 20'erne og 30'erne afspejler et Sarup-anlæg. Nogle af de neolitiske gruber ligger på række, og en enkelt af gruberne er næsten $20 \mathrm{~m}$ lang svarende til, hvad man kan forvente på et Sarup-anlæg.

\section{Rituelle knoglefund udenfor Danmark}

Vi har nu set en række skeletfund fra tragtbægerkulturen, som i høj grad antyder, at knoglerne har indgået i forskelligartede ritualer. Eksempler af lignende art kendes fra en lang række fund udenfor Danmark, bl.a. i Tyskland, Belgien, Frankrig og på De Britiske Øer.

\section{Tyskland, Frankrig}

I de mecklenburgske megalitgrave er det i flere tilfælde iagttaget, at skeletresterne ikke er sammenhængende, men derimod forefindes $i$ form af bunker af løse knogler, hvor hvert enkelt individ kun er repræsenteret ved en mindre del af skelettet (Schuldt 1966 (a) s. 50-52; 1966 (b) s. 74; 1972 s. 71-75 \& 1973 s. 8). Ofte kan kranierne ligge oven på knoglebunkerne. Disse forhold ses som udtryk for sekundære begravelser, d.v.s. at ligenes bløddele skulle være bortrådnet andetsteds før den endelige begravelse i megalitgraven. Udfra iagttagelserne i de mecklenburgske megalitgrave regnes det desuden for sandsynligt, at de rodede forhold, hvorunder knoglerne som oftest forefindes i de danske og svenske megalitgrave, ligeledes skal opfattes som henlæggelser af (løse) knogler, ikke begravelser af hele lig (Raddatz 1979 s. 133-134). Der tages dog ikke hensyn til, at der, som nævnt ovenfor, faktisk er iagttagelser fra ældre udgravninger, som bevidner begravelser af hele sammenhængende lig. Schuldts og Raddatz' tolkninger (ossarieteorien) af det ofte dårligt bevarede skeletmateriale fra Mecklenburg afvises da også fra nordisk side (Gräslund 1989 s. 72-74; Ebbesen 1975 s. 325; se også Knöll 1980).

På den anden side kan Midgley fremhæve to enkle firsidede dyssekamre fra Eversdorfer Forst-gruppen, der kan tyde på at man faktisk her har begravet et bevidst udvalg af allerede afkødede knogler (Midgley 1982 s. 445). Her fandtes i kamrene, der allerede i stenalderen er blevet forseglet, et knoglemateriale der kun repræsenterer dele af individerne. I Naschendorf-dyssen således et kranium uden underkæbe i kammerets hjørne, mens endnu et kranium lå i en lille grube, og enkelte knogler fandtes midt i kammeret. I Barendorf-dyssen lå knoglerne (et fragmenteret kranium, ribben og ryghvirvler, sammen med en kravefla- 
ske) i en bunke i kammerets hjørne. Det er dog et spørgsmål om disse forhold snarere bør tolkes som udtryk for hentning og ordning af knogler i dysserne end som begravelser af allerede afkødede knogler.

Et nøje bearbejdet knoglemateriale fra en kollektivgrav med delvis træbygget kammer, murkammergraven Odagsen i det sydlige Niedersachsen (Bernburgkultur), kan vise, at et knoglemateriale, som umiddelbart virker usammenhængende, og som derfor i første omgang kunne tolkes som udtryk for begravelser af knogler uden bløddele, faktisk blot afspejler oprydning i forbindelse med senere begravelser og en naturlig forfaldsproces inkl. dyrs aktivitet (Grupe $1984 \mathrm{~s}$. 141-144). Dette er dog fornylig blevet imødegået af Müller (1991 s. 57) og Beier (1991 s. 70), der mener, at de nævnte forhold ikke alene er tilstrækkelige til at forklare det rodede billede og skeletternes fragmenterede tilstand. I en anden af Bernburgkulturens kammergrave, Langeneichststädt ved Halle, fandtes finger- og tåknogler, ribben, tænder og en lårbensepifyse liggende indkapslet mellem brolægningens sten, således at der ved disse knogler næppe kan herske tvivl om, at der er tale om ægte sekundære begravelser af allerede afkødede enkeltknogler (Müller 1988 s. 193 ff \& 1991 s. 57).

Også fra Mellemtyskland (bl.a. Walternienburg-og Baalberg-grupperne) haves ældre udgravningsvidnesbyrd, som fortæller om begravelser af hele lig, enten i udstrakt rygleje eller i hocker, men også om rod og uorden, ordning af visse knoglekategorier, som f.eks. kranier samt begravelser af kranier eller kraniedele (Beier 1984 s. 22, 28-29 \& 41-44; Heege 1989; Happ 1991 s. 85, 90, 314 \& 320; om kugleamforkultur se Kirsch 1991 s. 75 ff).

Det er dog ingenlunde så enkelt, at man blot bør diskutere hvorvidt begravelserne skal anses for egentlige begravelser af hele lig eller begravelser/deponering af knogler. Som det er fremgået af gennemgangen af det nordiske materiale, så kan visse knogler i nogle tilfælde være fjernet fra megalitgraven, sikkert til brug for ritualer andetsteds. Selvom der måske næppe er tilstrækkelige vidnesbyrd, der taler for en egentlig gravlæggelse af allerede skeletterede knogler i Mecklenburgs megalitgrave, så er der dog stadig meget, der tyder på, at ritualer med knoglerne faktisk har fundet sted. Det vil ellers være overordentligt vanskeligt at forklare, hvorfor der i et af lagene i en jættestue ved Liepen fandtes 6 kranier, men kun 3 underkæber (Schuldt 1972 s. 74). I flere andre tilfælde er det iagttaget, at kranierne ligger ovenpå en knogledynge, ofte uden underkæben (Raddatz 1979 s. 133). Årsagen kan i disse tilfælde ikke være bevaringsforholdene, idet det er underkæberne, som regnes for de mest robuste (Bennike 1985 s. 471). Noget må således være fjernet, givetvis af rituelle årsager.

Ejheller i Frankrig er forholdene entydige. Også her findes der megalitgrave, hvor der forekommer begravelser af hele skeletter, men desuden findes der et stort antal grave, hvor knoglerne ligger som enkeltknogler uden organisk orden eller sammenhæng, hvad der ligesom i Danmark gerne tolkes som udtryk for en oprydning i kammeret i forbindelse med senere begravelser. I visse tilfælde er iagttaget en ordning af knoglerne, f.eks. kan kranierne være samlet (Joussaume 1988 (a) s. 125-126; Giot 1983 s. 23-26; Mohen 1989 s. 227-228). I megalitgraven La Chaussée-Tirancourt ved Somme (med begravelser fra mellemneolitisk tid til og med begyndelsen af hvad der svarer til vor senneolitiske tid) er nogle af de begravede kun repræsenterede ved kraniet, andre mangler kraniet (Duday \& 
Masset 1989 s. 170 \& 174). Her må noget igen være fjernet eller ikke være kommet med i kammeret. Et ganske spektakulært eksempel på rituel brug af kranier kendes fra en grottegrav ved La Baume de Fontbrégouda i Dep. Var, hvor man har udgravet seks kraniekalotter skåret i stykker med flintknive og spredt over nogle kvadratmetre (Mohen 1989 s. 230). I megalitgraven La Houge i Normandiet lå knoglerne i ét rod, og der var otte underkæber, men ikke ét kranium. Det er bemærkelsesværdigt, at mange af ligene i megalitgraven La Hoguette kun få hundrede meter derfra er sammenhængende og komplette. Forholdet mellem de to åbenbart samtidigt benyttede megalitgrave tolkes således, at når kammeret i La Hoguette var fuldt, da blev knoglerne samlet sammen og placeret i kammeret i La Houge, mens nogle af knoglerne - for eksempel kranierne - blev holdt tilbage og bragt til bopladsen eller måske et Sarup-anlæg. Også i Vendee-regionen i midt-vest-Frankrig er tilsvarende forhold iagttaget, og igen tolkes dette som udtryk for, at man fra tid til anden har tømt et kammer for sit indhold af knogler og ført dem til en placering andetsteds (Joussaume 1988 (b) s. 294-298). Det udelukkes ikke, at man i de franske megalitgrave også kan have begravet allerede skeletterede knogler.

Ligesom ovenfor antydet vedrørende det danske materiale kan et "andetsteds" være de store rituelle grøftanlæg, som også i de seneste år er fundet i stort tal i Frankrig. Herfra er der fremkommet utvetydige vidnesbyrd om rituel omgang med menneskeknogler, f.eks. kendes fra Champ Durand i Vendee flere nedlæggelser af kranier uden underkæber eller underkæber uden kranier (Joussaume 1988 (b) s. 294) samt begravelser af hele og sammenhængende skeletter. Tilsvarende forhold er iagttaget på grøftanlægget ved Machecoul, Loire Atlantique, hvor der især ved enderne af grøfterne fandtes kraniekalotter (L'Helgouach 1988 s. 272).

Også fra belgiske og tyske grøftanlæg af denne type kendes en lang række fund af nedlæggelser af enkeltknogler af rituel art. Vi kan nævne veldokumenterede fund fra Spiennes i Belgien, hvor der er flere nedlæggelser af kranier (Verheyleweghen 1962 s. 198 ff). Alle kranier, hvor man kender tilstrækkeligt til deres fundforhold, er fundet nedlagt enten alene eller to og tre sammen, uden andre menneskeknogler og uden deres underkæbe. De er alle forsætligt dækket af et lag jord. Udover kraniekalotterne er der på stedet fundet nedlæggelser af enkelte underkæber og lange lemmeknogler.

På eponymlokaliteten for Michelsbergkulturen, Michelsberg (også benævnt Untergrombach) i Sydvesttyskland, er der en lang række nedlæggelser af menneskeknogler uden anatomisk orden. Her er det andre knogler end kraniet, som dominerer. Ofte ligger flere forskellige knogletyper sammen, og knogler fra samme individ kan findes i forskellige nedlæggelser (Lüning 1968 s. 306 ff). I næsten alle tilfælde er knoglerne uden nogen anatomisk sammenhæng. Der er også nedlæggelser af oksekranier sammen med menneskekranier (jævnfør den danske Hygind-lokalitet). Vi kan herfra nævne fund 25, hvor to barnekranier var nedlagt omgivet af sten og ledsaget af okseknogler. Det ene kranium var uden underkæbe, det andet med. I underkæbebuen lå ribbensstykker og en fingerknogle. Ikke langt fra Michelsberg er der ved Aue for nylig undersøgt et grøftanlæg (Behrends 1991 s. 29 ff) med nedlæggelser af oksehorn samt egentlige begravelser med skeletter i organisk orden, hvor der ikke var fjernet noget. 


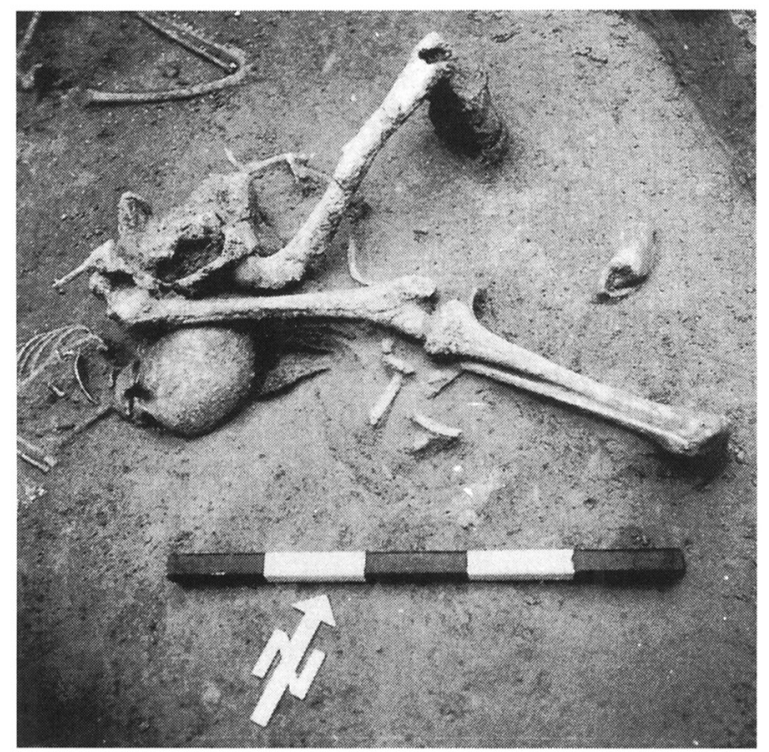

Fig. 10. Nedlæggelse af knogler fra en kvinde, hvor kraniet mangler, i en grøft på grøftanlægget Aue ved Michelsberg. Under disse skeletrester ses $i$ venstre side af billedet det ene af de to barneskeletter, efter Behrends 1991.

Deposit of bones belonging to a woman, skull missing, found in a ditch of the causewayed enclosure at Aue near Michelsberg. Under these on the left can be seen one of the two child skeletons (after Behrends 1991)

Fig. 11. Kranier, andre knogler og et lerkar liggende i en grøft i grøftanlægget Heidelsheim i Baden. (Efter Maier 1962).

Skulls, other bones, and a pot, lying in a ditch of the causewayed enclosure at Heidelsheim in Baden (after Maier 1962).

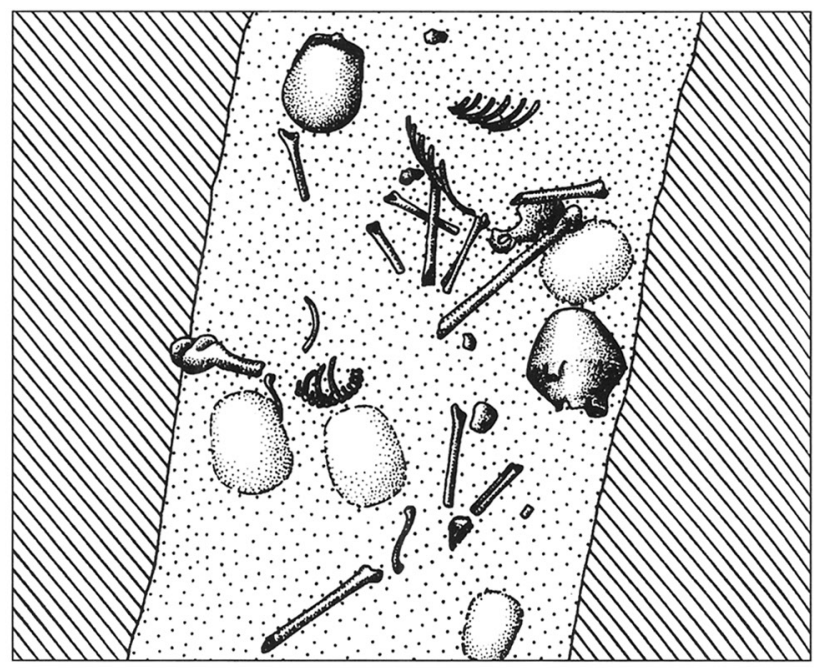

Disse begravelser repræsenterer ingenlunde et befolkningstværsnit; de døde, der blev begravet her må være udvalgt efter særlige kriterier, idet der enten er tale om børn eller ældre individer. Igen er der særegne knoglefund (ibid s. 34-35). Således fandtes en nedlæggelse af skeletdele fra en voksen kvinde, hvor kraniet manglede (fig. 10), sammen med dyreknogler og to hele skeletter af børn. Desuden fandtes der flere steder i grøfternes bund kraniebrudstykker. Vidnesbyrd om for os besynderlige ritualer med menneskeknogler fra Michelsbergkulturen kendes også fra en hule ved Kleinkems, hvor der i en fordybning i hulegulvet lå menneskeknogler uden organisk sammenhæng samt et kranie med en fingerknogle i sit indre (Lüning 1968 s. 129). 
Selvom vi på alle grøftanlæggene ser en tydelig interesse for kranier eller underkæber, så er der dog væsentlige forskelle i udvalget af knogler og de dødes alder og køn, hvad der fremgår af en sammenligning mellem Michelsberg og et andet grøftanlæg i Sydvesttyskland, Heidelsheim (fig. 11). På Michelsberg er der tydelig overvægt af de lange lemmeknogler i forhold til de påfaldende sparsomt forekommende kraniedele, mens forholdet på Heidesheim er mere ligeligt. Derimod mangler på Heidesheim de knogler, som ikke hører til hoved, arme og ben, f.eks. ribben og hvirvler, og armknoglerne er i forhold til benene meget talrige. På Michelsberg er der nogenlunde lige mange mænd og kvinder, mens kvinderne overvejer på Heidesheim. På Michelsberg udgør børnene mindre end $1 / 5$, på Heidesheim er $2 / 3$ børn. For begge lokaliteter gælder det, at det kun er fă knogler fra hvert individ, som er nedlagt, og at der ikke er fundet begravelser af hele, sammenhængende lig. Andre lokaliteter rummer lignende vidnesbyrd om komplicerede ritualer (Maier 1962 s. 15 ff).

Fra tragtbægerkulturens tid kendes også nedlæggelser menneskeknogler, især kranier, fra "gruber" eller "bopladsgruber" (Happ 1991 s. 88, 238 \& 262), hvor der i flere tilfælde kan være tale om fund fra ikke erkendte grøftanlæg (19).

\section{De Britiske Øer}

Fra De Britiske Øer kender vi en række meget væsentlige fund samtidige med vor tragtbægerkultur, der oplyser om ritualer med menneskeknogler, både fra megalitgrave og fra de store grøftanlæg, som her benævnes causewayed enclosures. Igen vil vi se, at forholdene ikke er entydige; såvel i megalitgravene som på causewayed enclosures findes både begravelser af hele lig, knoglebunker uden organisk sammenhæng, og nedlæggelse af enkelte kranier eller kraniedele.

I den sydengelske ikke-megalitiske langhøj, Fussel's Lodge Long Barrow's østende (Ashbee 1966), hvor der er rester af en kammerlignende trækonstruktion, fandtes et gravlag med 4 bunker af menneskeknogler uden nogen organisk sammenhæng repræsenterende 53-57 individer; kun ganske få knogler fra hvert individ var til stede. I bunkerne er de lange lemmeknogler lagt pænt efter højens akse, kraniedele eller kranier lå som oftest øverst. En særlig overvægt af barneunderkæber i en af bunkerne er påfaldende. I Fussel's Lodge Long Barrow anses de mange fragmenterede knogler og tilstedeværelsen af kun nogle fă knogler fra hvert individ som udtryk for sekundær begravelse, d.v.s. at knoglerne har været begravet eller lagt ud til afkødning for den endelige begravelse (se også Scott 1992 s. 104 ff).

Den Sydengelske megalitgrav West Kennet Long Barrow (nær det gigantiske henge-monument Avebury) med et stort jættestuelignende kammer har ydet et interessant knoglemateriale (Piggott 1962). I kammeret var der både hele eller næsten hele skeletter og knogledynger repræsenterende ca. 40 individer. Nogle kranier og lange lemmeknogler var ordnet langs kammerets vægge. Et af de sammenhængende skeletter mangler såvel kranium som underkæbe. Der var tydeligvis for mange underkæber i forhold kranier, ligesom der var for fă lange ekstremitetsknogler i forhold til antal individer repræsenteret. Udgraveren mener, at de manglende knogler er fjernet fra kammeret.

Fra megalitgraven Lanhill i Sydengland stammer bl.a. seks kranier, ni underkæber og lemmeknogler nok til elleve individer (Keiler \& Piggott 1938 s. 124 
ff; Piggott 1962 s. 66; King 1966 s. 82). Altså igen en fordeling, som tyder på et bevidst udvalg af knogler. Også her ses knoglebunker omfattende flere individer. En lille detalje er, at der i et tilfælde er sat en forkert underkæbe på et af kranierne.

En nylig undersøgt megalitgrav, Hazleton North, også Sydengland, har ydet et særdeles velbevaret knoglemateriale (Saville 1990 s. 250 ff). Materialet omfatter rester af ca. 40 individer, mænd, kvinder og børn, som udfra C14-dateringer er blevet begravet indenfor en forholdsvis kort periode på omkring 100 år. Den meget omhyggelige udgravning og analyse af knoglematerialet viser, at de døde er blevet bragt til megalitgraven som hele lig. Der er intet der tyder på, at man har placeret enkeltknogler i graven, dog bortset fra nogle brændte ben i det ene kammer. Først ved den gentagne brug af de to kamre er der blevet rodet rundt med knoglerne fra tidligere gravlagte. Nogle gange må kun halvt forrådnede lig være flyttet, idet knogler fra visse dele af krop og lemmer stadig lå i rigtig sammenhæng (ganske som i vore danske jættestuer). Knogler fra samme individ har man søgt at samle i bunker, og ofte er kranierne lagt langs kammerets vægge. Visse knogler mangler, nemlig nogle af de lange lemmeknogler samt antagelig kranier. En af de sidst begravede i Hazleton North lå urørt som et helt skelet.

Udgravningsresultaterne og knoglematerialet fra megalitgraven Ascott-underWychwood er blevet tolket ret forskelligt af henholdsvis en fysisk antropolog, der har behandlet knoglematerialet, og udgraverne (der dog åbenbart også har en vis anatomisk skoling). Antropologen mener, at det spredte og delvis forvitrede knoglemateriale fra langhøjens to kamre uden tvivl afspejler begravelse af allerede afkødede knogler (Chesterman 1977), dog åbenbart uden at tage hensyn til vigtige udgravningsmæssige data (ibid. s. 29), mens udgraverne mener, at først og fremmest hele lig er begravet (Benson \& Clegg 1978 s. 135). Diskussionen om knoglefundene i denne megalitgrav er lærerig; den fortæller om vanskelighederne ved tolkningen af de ofte spredte menneskeknogler. Selvom der i Ascott-under-Wychwood åbenbart er gode vidnesbyrd om begravelse af lig "med kød på", så udelukkes det ikke, at der tillige kan have fundet begravelser sted af afkødede enkeltknogler i løbet af kamrenes brug, ligesom det ingenlunde udelukkes, at knogler kan være fjernet fra kamrene til brug for ritualer andetsteds (Benson \& Clegg 1978 s. 136-137).

På alle de engelske grøftanlæg, causewayed enclosures, hvor bevaringsbetingelserne er til det, er fremkommet menneskeknogler. Væsentligst er i denne sammenhæng Hambledon Hill i Sydengland, hvor der i primær position i grøfterne er undersøgt et meget stort antal rituelle nedlæggelser af menneskekranier uden påsiddende halshvirvler, hvad der viser, at kød og sener var bortrådnet før nedlæggelsen (Mercer 1990 s. 50-51). Næsten altid mangler underkæben. Kranierne var pænt sat på bunden af grøfterne og var nogle gange ledsaget af bunker af keramik, flint og dyreknogler (Mercer 1975 s. 18). I samme fase af grøftanlægget fandtes tillige nedlæggelser af de lange lemmeknogler. I en senere fase på Hambledon Hill er flere underkæber til stede (Mercer 1980). Det samme billede fremviser fundene af menneskeknogler på grøftanlægget ved Windmill Hill ikke langt fra the West Kennet Long Barrow: spredt i grøfterne fandtes 11 kraniefragmenter, 4 overarme, 4 lårben, 1 albueben, 1 lægben og 1 ryghvirvel (Smith 1965). 
Det er vigtigt at notere sig, at netop de knoglekategorier, som er underrepræsenteret i megalitgravene, nemlig kranier og lange ekstremitetsknogler (som West Kennet Long Barrow og Hazleton North), findes særligt hyppigt som nedlæggelser på grøftanlæggene. Det er nærliggende at tro, at denne bemærkelsesværdige sammenhæng afspejler en "trafik" af knogler fra megalitgravene til grøftanlæggene som led i komplicerede og langvarige ritualer omkring de døde og deres knogler (selvom de nævnte fund fra henholdsvis megalitgravene og grøftanlæggene ikke nødvendigvis behøver at være fuldstændig kronologisk sammenfaldende). Noget lignende kan med lidt god vilje skimtes i det langt ringere og usikrere danske materiale. Som nævnt var der alt for mange underkæber i forhold til kraniefragmenter i dyssen ved Trekroner, ligesom der muligvis mangler kranier i Hulbjerg-jættestuen. Omvendt er der i grøftanlægget ved Hygind kranier uden underkæber, og ved Bundsø er fremkommet dele af flere kranier, men ingen underkæber.

På Hambledon Hill findes også egentlige begravelser af hele lig, hvad der også gælder andre af de sydengelske grøftanlæg som Windmill Hill, Whitehawk, og Offham (Drewett 1977 s. 225). Men der er tillige fund, der antyder, at en afkødning af lig har fundet sted på grøftanlæggene. På Hambledon Hill fandtes således den sammenhængende krop med lårben af en mand, hvis lig åbenbart var begyndt at gå i opløsning; de bevarede dele af ham må åbenbart være trukket ned i grøftens bund af hunde, som har gnavet på knoglerne (Mercer $1988 \mathrm{~s}$. 95). Spredte og mere "tilfældigt" forekommende knogler i grøfternes forsætligt tilbagefyldte jordmateriale på bl.a. Hambledon Hill (Mercer 1990 s. 57) og Offham (Drewett 1977) antyder også at causewayed enclosures har haft en sådan funktion. Man bør følgelig ikke helt udelukke, at en "trafik" med knogler kan have gået den anden vej, fra grøftanlæg til megalitgrav (Mercer 1990 s. 51).

Det velbearbejdede knoglemateriale fra såvel grøftanlæggene som megalitgravene i det sydlige England, hvor bevaringsforholdene i flere tilfælde er optimale, mere end antyder, at der i forbindelse med de åbenbart komplicerede og langvarige grav- og døderitualer i neolitikum kan have været et samspil mellem grøftanlæg og grav, og at "den endelige gravlæggelse" ikke nødvendigvis behøver at være ét sted.

\section{Orkney}

Også fra de interessante megalitgrave på Orkney-øerne udfor Skotlands nordøstkyst (et sluttet område med en høj forskningsstandard) har det velbevarede knoglemateriale givet vidnesbyrd angående begravelsesformen og ritualerne.

Fra jættestuen Quanterness på Mainland er publiceret et velanalyseret knoglemateriale. Fra den del som undersøgtes, kunne mindst 157 individer identificeres, hvor kun fă knogler repræsenterer hvert individ (Renfrew 1979 s. 166 ff). De mest almindelige knogletyper er de små hånd- og fodknogler samt ryghvirver, mens der er en bemærkelsesværdig underrepræsentation af kranier og lange lemmeknogler. C14-dateringer af knoglerne fortæller, at begravelserne har fundet sted igennem en længere periode. Bortset fra en næsten hel begravelse i en grube under kammerets gulv (den første begravelse), og den antagelig sidste begravelse øverst i det tykke knoglelag fandtes ingen hele skeletter, alt var et rod af usammenhængende knogler, hvor der blot i ét tilfælde fandtes 


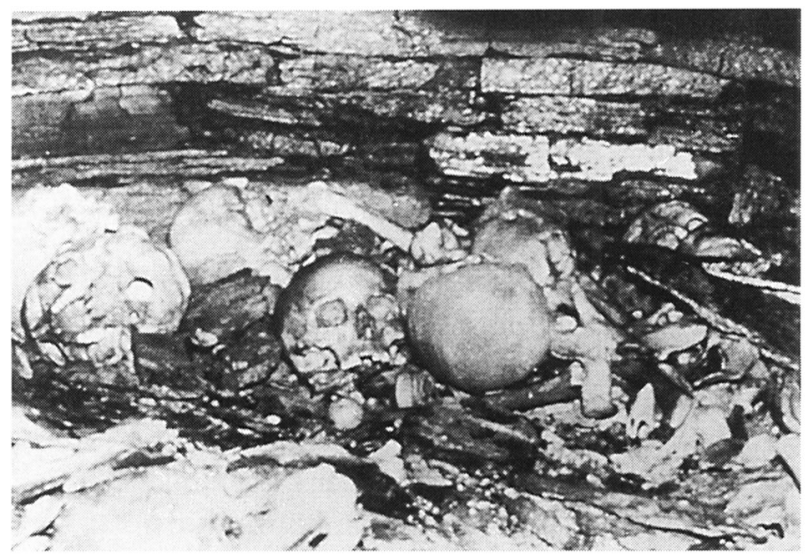

Fig. 12. Et kig ind i et af de to sidekamre i Isbister-megalitgraven, South Ronaldsay, Orkney, hvor der mest lå kranier. (Efter Hedges 1987).

View into one of the two lateral chambers in the megalithic tomb at Isbister,South Ronaldsay, Orkney, where there were mostly skulls.

dele af et individ $i$ anatomisk sammenhæng (Chesterman 1979 s. 105). Næsten alle disse spredte knogler var let brændt. Forholdene i Quanterness tolkes af udgraveren som udtryk for afkødning af de døde andetsteds før den endelige begravelse af enkeltknogler i megalitgravens kamre. De mange små knogler fra fødder og hænder skulle følgelig afspejle, at man i stenalderen var omhyggelig med at få disse samlet sammen, mens manglen på kranier og lange knogler bør afspejle en brug $i$ anden sammenhæng.

Lignende forhold i megalitgraven Isbister på South Ronaldsay er tolket på samme måde. Igen var hvert individ kun repræsenteret ved fă knogler uden anatomisk sammenhæng. Der er rester af mere end 300 individer. I enkelte tilfælde kunne det fastslås, at løse knogler til enkelte individer lå samlet i en bunke med kraniet øverst. I sidekamrene fandtes næsten udelukkende kranier (fig. 12), mens kranier var placeret ovenpå knoglebunker langs hovedkammerets vægge; $\mathrm{i}$ særlige båse $\mathrm{i}$ hver ende af hovedkammeret var der til gengæld ingen kranier (Hedges 1984 s. 59 \& 136; Sharples 1985 s. 68; Davidson \& Henshall 1989 s. 53-54 \& 125-130). Meget tyder således på, at man i hvert fald for nogle af de begravedes vedkommende først har placeret de jordiske rester af de (allerede andetsteds) afkødede døde i hovedkammeret og arrangeret knoglerne i bunker omfattende et enkelt individ; senere har man sorteret knoglerne, således at kranierne pænt lagdes i sidekamrene, mens de øvrige knogler blev placeret i båsene i hver ende af hovedkammeret. En tydelig underrepræsentation af kranier er værd at notere sig. Under den ene ende af hovedkammeret fandtes en bunke knogler uden organisk sammenhæng (repræsenterende 15 individer), som må være placeret dér før kammeret opførtes. En enkelt knogle fra selve kammeret ovenover kan med sikkerhed relateres til et af individerne i denne bunke; - et vægtigt argument for, at der faktisk har fundet begravelser af afkødede knogler sted i forbindelse med opførelsen og den første brug af denne megalitgrav.

Men ejheller indenfor et mindre, sluttet område som Orkney-øerne er forholdene entydige. Andre af øgruppens megalitgrave dokumenterer begravelse af hele sammenhængende lig; skeletter i hocker kan ligge på stenhylder med ryggen mod væggen. Efter bløddelenes bortrådnen har man bunket de løse knogler sammen, med kraniet ovenpå eller stående ved siden af, eller knoglerne 
er blevet samlet i enden af kammeret eller under hylden. Løse kranier kan være placeret inderst. Knowe of Yarso, Rousay, yder et eksempel på en kompliceret gravlæggelsessekvens, hvor det enkelte hele lig antagelig "startede" i kammerets ydre del og efterhånden blev opsplittet, sorteret, og hvor dele endte bagest. I forbindelse med denne ordning og opsplitning blev noget fjernet fra megalitgraven, i dette tilfælde underkæber, som fuldstændig mangler fra de mindst 29 individer, hvis jordiske rester fandtes her (fig. 13). Tilsvarende forhold er iagttaget i den nærliggende megalitgrav Midhowe (Richards 1988 s. 49; Davidson \& Henshall 1989 s. 54-55). I nogle megalitgrave mangler kranier eller er underrepræsenteret, i andre er der for mange (Richards 1988 s. 46), i Midhowe er seks af de begravede kun repræsenteret ved deres kranier (Henshall 1985 s. 100). Selvom begravelsesskikken i mange tilfælde har været begravelse af hele lig, så er der åbenbart fjernet noget og givetvis udført ritualer med knoglerne.

På Orkney er der ikke fundet causewayed enclosures (Sarup-anlæg), men der er dog et par lokaliteter, som fortæller, hvor de fra megalitgravene fjernede knogler kan være endt. Fra bopladsen Knap of Howar, Papa Westray, med de to

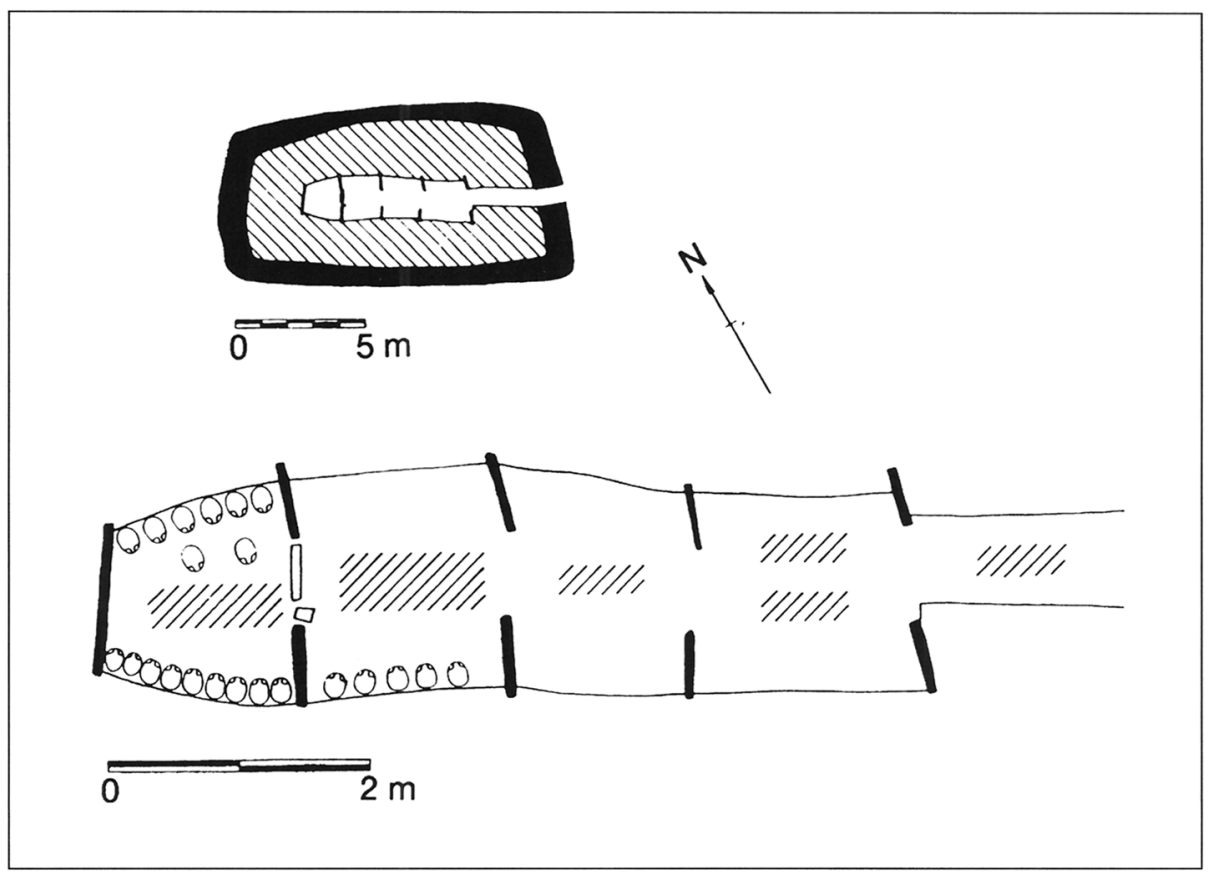

Fig. 13. Skematisk tegning af bås-megalitgraven (stalled cairn) Knowe of Yarso, Rousay, Orkney, angivende positionen af de forskellige begravelseskategorier: langs siderne $i$ kammerets inderste del og den næstinderste dels sydside stod kranierne så de "kiggede" mod kammerets midte. I inderste og næstinderste dels midte fandtes blandede knogler (skraveret), mest lange knogler, mens de skraverede partier i gangen og de to yderste kammerdele viser ukomplette og lidt rodede skeletbunker af enkeltindivider. (Efter Richards 1988).

Schematic plan of the stalled cairn, Knowe of Yarso, Rousay, Orkney, showing the position of different bone categories. Along the sides of the innermost part of the chamber and the southern side of the next innermost part the skulls stood facing towards the centre of the chamber. In the middle of the innermost and next innermost part there were mixed bones (shaded), mostly long bones. The shaded parts of the passage and two outer parts of the chamber indicate incomplete and somewhat disturbed bone heaps of individual burials (after Richards 1988). 
velbevarede neolitiske huse stammer et stykke af et menneskekranie, og på Knoll of Skulzie, Westray, er udgravet en nedlæggelse af et stort antal menneskekranier sammen med to slebne stenøkser (Richards 1988 s. 49-50).

Der er af gode grunde rejst kritik af kun at tolke forholdene på Orkney således som resultaterne fra Quanterness og Isbister synes at vise (Davidson \& Henshall 1989 s. 54-55). Ja, meget tyder på, at det kun er for disse to grave, at egentlig begravelse af allerede afkødede knogler med sikkerhed kan påvises. Der er utvivlsomt gået for langt, når Renfrew i Quanterness-publikationen bemærker: "Indeed it seems likely that a careful re-examination of the evidence would show excarnation to have been the norm rather than the exception among the burial practises of neolithic Britian, and that the interment of complete bodies in collective burial chambers was always unusual" (Renfrew 1979 s. 167).

Det kan iøvrigt fremhæves, at mange af de argumenter, der fremføres for en afkødning før den endelige begravelse i gravkammeret, også kan benyttes, hvis man i stedet vælger at tolke forholdene således, at man fra først har placeret ligene hele i graven, og derefter i forbindelse med mange besøg her har rodet rundt med knoglerne og ordnet dem samt fjernet visse knogler til brug i forskellige ritualer. Variationen i gravritualerne i Quanterness, hvor der både konstateredes hele begravelser og knogledynger uden orden, er i sig selv en advarsel om, at situationen er ganske kompleks (Davidson \& Henshall 1989 s. 58-59).

Netop Isbister og Quanterness adskiller sig fra de øvrige af Orkneys undersøgte megalitgrave ved det meget høje antal individer repræsenteret, ca. 350 for Isbister og ca. 400 for Quanterness (hvis vi antager, at de ikke undersøgte dele af Quanterness indeholder den samme mængde knogler som de undersøgte). Selvom der som oftest er tale om ældre undersøgelser, synes individtallene ellers ikke tilnærmelsesvis at være så høje; de højeste er 25 for Midhowe og 29 for Knowe of Yarso. Det kan således ikke udelukkes, at netop Isbister og Quanterness har haft eller har fạet en særlig status, at de kan være brugt som deponeringssted for afkødede knogler, der er hentet $\mathrm{i}$ andre megalitgrave (Richards 1988 s. 55). Som nævnt ovenfor, er forholdene i et par tætliggende franske megalitgrave tolket på samme måde.

Forskellene mellem de megalitgrave på Orkney, hvor der kendes begravelser af hele lig og de megalitgrave, hvori der åbenbart er placeret afkødede knogler, er for nyligt tolket som udtryk for en udvikling i samfundene. Begravelser af hele lig anses for forholdsvis tidlige hørende til mindre samfund, hvor individet og dets relationer var af størst betydning, mens begravelser af afkødede knogler anses for afspejlende større samfund, hvor det er dette større samfund og identifikationen med dette, der skulle markeres ved, at man fjernede knogler fra den "lokale" megalitgrav og placerede dem i andre (åbenbart centrale) megalitgrave. (Sharples 1985 s. 70 ff; Richards 1988 s. 55). "The destruction of individual ancestors and their spheres of influence effectively creates a unified ancestral body.... No longer are ancestors identifiable or accesible, but are instead monopolised by a small element of the living" (Richards 1988 s. 55).

Også på det skotske fastland, især Caithness, er der gjort interessante iagttagelser angående begravelsesformerne. Det skal blot nævnes, at der synes at have fundet såvel begravelser af hele lig som af knoglebunker sted. I et tilfælde er få enkeltknogler nedlagt under et kammers gulvbelægning (Corcoran 1967 s. 48 
ff; Henshall 1985 s. 105; Sharples 1986 s. 2 ff; Davidson \& Henshall 1991 s. 60 ff). Også her kan der inden for et mindre område konstateres flere vidtforskellige måder at nedlægge menneskets jordiske rester på, også selv blandt helt tæetliggende megalitgrave (20).

\section{Rituel brug af knogler i enkeltgravskultur}

Fund, som til en vis grad kan sammenlignes med knoglenedlæggelsen fra Jordehøj er sjældne, hvilket måske kunne skyldes, at bevaringsforholdene for knogler i gravfund fra enkeltgravskultur er ringe. Mange fund, hvor man som en skygge kan ane et ligs placering i grave fra denne tid, viser dog, at hele begravelser har været reglen. Fra den skånske gravplads ved Bedinge foreligger et knoglemateriale, der viser, at der også i enkeltgravstid udførtes ritualer med dele af menneskeskelettet (During 1989). I pladsens grav 47 fandtes nederst et helt skelet af en ung kvinde. Udenfor gravkonstruktionen lå to samlinger knogler, den ene med kranierester (inklusive underkæbefragmenter) af et 7-8 år gammelt barn, den anden med store dele af kraniet (uden underkæbe), ryg- og halshvirvler, ribben og armknogler fra et 10-årigt barn samt kraniefragmenter og del af en halshvirvel fra to andre individer. Over kvindegravens underben fandtes en bunke knogler fra mindst ni individer. Knoglerne er mest lange knogler samt fem kranier, som indrammes af de øvrige knogler. Der er en væsentlig underrepræsentation af underkæbedele. Antagelig er de fem hele kranier nedlagt uden underkæber. Ligdele må være nedlagt, hvis kød allerede var bortrådnet eller delvis bortrådnet, idet der ikke konstateredes skære- eller hugmærker på knoglerne. Manglen på visse knogletyper kunne skyldes bevaringsmæssige forhold, men underrepræsentationen af underkæbeknogler, som regnes for at være mere holdbare end f.eks. kranieknogler, kan ikke forklares på denne måde. Vi må stå overfor en nedlæggelse af rituel karakter af udvalgte knogler. Denne grav er udfra gravtypen og gravgodset dateret til sidste fase af stridsøksekulturen eller til overgangen til senneolitikum. En tandemaccelerator-datering af primærgraven angiver en datering ved midten af stridsøksetid, mens en datering af knogledyngen ligger ca. 1000 år senere, i ældre bronzealder. Her er der et problem. Kan det virkelig tænkes, at man 1000 år senere har gravet ned i en dyb jordfæstegrav uden at forstyrre den primære begravelse overhovedet, for at foretage en rituel nedlæggelse af udvalgte knogler? Hele anlægget med primærgrav og knogledynge virker som en helhed, og det er da også sådan den tolkes af During (1989), på trods af de to C14-dateringer, som fremlægges i samme afhandling. I et sådant tilfælde bør man overveje, om den ene datering på en eller anden måde er blevet forurenet med yngre materiale.

Fra Metzendorf-Woxdorf, Kreis Harburg i Nordtyskland, stammer et fund fra enkeltgravskulturen, der klart vidner om særlige begravelsesritualer i forbindelse med kraniet (Wegewitz 1960). Under flad mark fremkom ved anlægsarbejde en kraniebegravelse af en voksen mand, hvor kraniet fandtes liggende i en skål dækket af et større lerkar sat omvendt. Det større lerkar var nederst omgivet af en pakning af sten, mens skålen med kraniet stod på tre mindre sten (fig. 14). De øvre dele af kraniet, som lå i det jordfrie hulrum, var til stede, mens de nedre dele og underkæben ikke var bevaret. De fundne stykker tandemalje synes at 


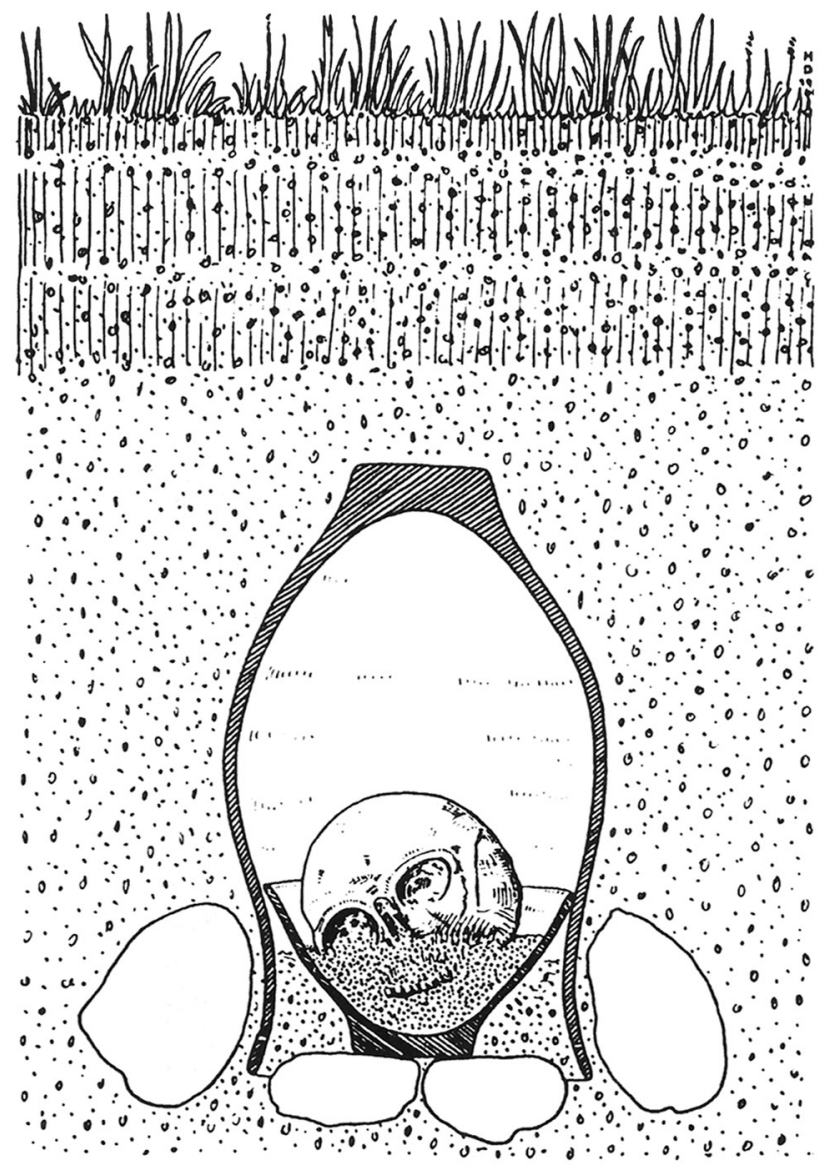

Fig. 14. Kraniebegravelse fra enkeltgravskultur ved Metzendorf-Voxdorf, Nordtyskland; over og omkring det meste af kraniet var der stadig ved undersøgelsen et jordfrit hulrum. (Efter Wegewitz 1960).

Burial of a skull from the Single Grave Culture, Metzendorf-Voxdorf, northern Germany. When excavated there was a cavity without earth over and around most of the skull (after Wegewitz 1960).

tilhøre overkæben og antyder, at kraniet oprindelig begravedes uden underkxbe.

Også fra Succase i det nordøstlige Polen, er der gjort fund, der må anses for vidnesbyrd om kranieritualer indenfor enkeltgravskultur. I en grube ved et hus fandtes således en underkæbe uden kranium og fra en anden grube på stedet foreligger blot dele af en kraniekalot. I en tredje grube fandtes en underkæbe omgivet af ca. 25 ravperler og en lille flintmejsel (Happ 1991 s. 86 \& 308). Også fra Böhmen stammer en antagelig snorekeramisk nedlæggelse af et kvindekranium samt marvspaltede armknogler antydende kannibalisme (ibid. s. 87 \& 271).

\section{Rituel brug af menneskeknogler i senneolitikum og bronzealder}

\section{Senneolitikum}

Et godt eksempel på ritualer med menneskeknogler stammer fra en senneolitisk gravplads ved Lille Vasby mellem København og Roskilde (Liversage 1966 \& 


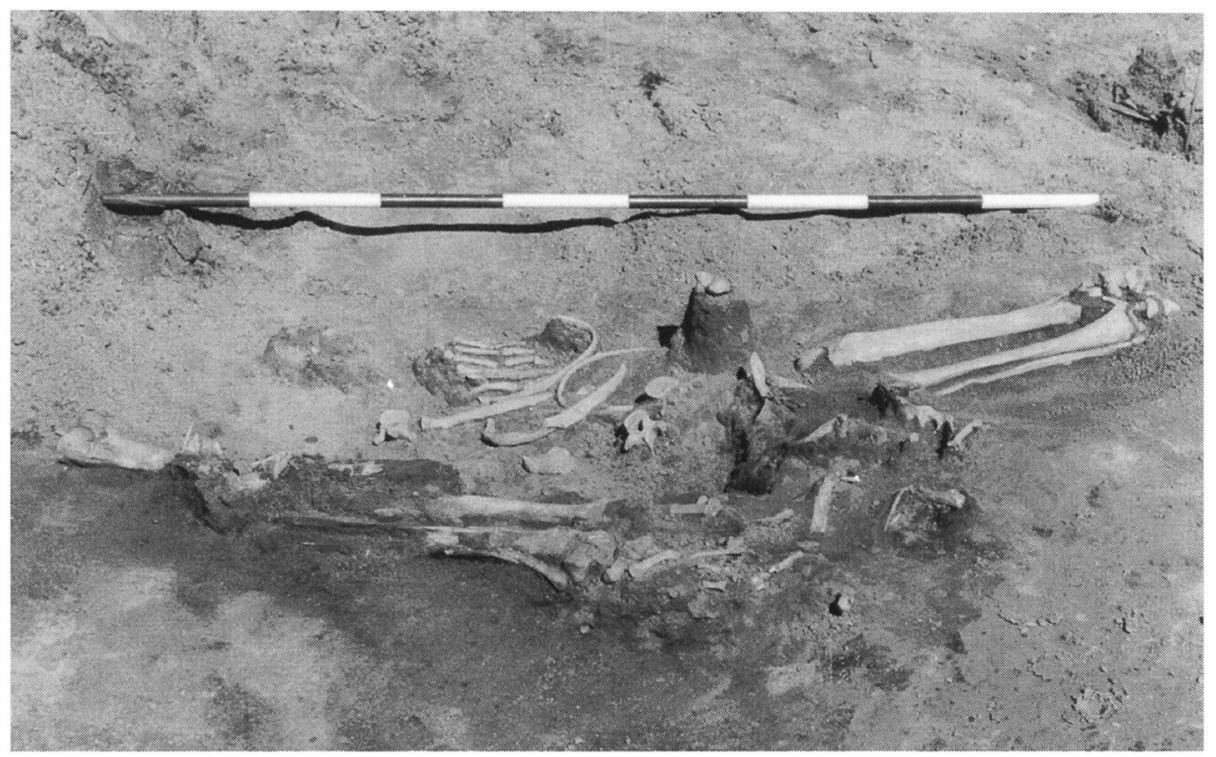

Fig. 15. En knogledynge fra Lille Vasby, Sjælland; det fremgår tydeligt, at noget mangler, og at der er rodet rundt med knoglerne. Foto: D. Liversage.

A heap of bones at Lille Vasby. It is obvious that something is missing and that disturbance has taken place.

1980 s. 25-26). I en fællesgrav (ikke hellekiste) fandtes skeletrester af tre voksne individer, hvor kranierne og de fleste lemmeknogler manglede. De tilbageværende knogler lå hulter til bulter; urørt var kun partier af de nedre dele af benene (fig. 15). Knoglerne i graven må være fjernet efter at kødet var bortrådnet. I en stor nærliggende grube fandtes nogle af disse knogler sammen med andre knogler. Fire kranier lå hver for sig. Knogleresterne var som regel uden organisk orden, men i to tilfælde lå halshvirvler sammen med kraniet. Mange lemmeknogler var lagt parallelt. Der fandtes ialt fem barnekranier, et med tilhørende underkæbe, og to kraniebrudstykker lå i hver sin runde fordybning i den store grubes bund.

I mange senneolitiske hellekister er knogler ryddet væk fra selve gravrummet for at blive placeret foran kistens indgang. I disse tilfælde er det naturligvis vanskeligt at sige om denne fjernelse af knogler var rituelt betonet, eller om der blot var tale om et ønske om at rydde op i kisten for at skaffe plads til den næste begravelse (13) (Liversage 1965 s. 45). Man finder ofte den sidst begravede i hel tilstand; men når derimod alle knogler, hvad der er iagttaget $\mathrm{i}$ en hellekiste ved Thorkildstrup og ved Ejby, begge i Roskildes omegn, ligger sammenblandet, kan man slutte, at kammeret har været åbnet en sidste gang, med et andet formål end en egentlig begravelse (Liversage 1965 s. 45 \& 1966 s. 7). Det samme er tilfældet ved en hellekiste ved Saltvik i Skåne (Forssander 1936 s. 142).

Også fra megalitgravene kendes der senneolitiske begravelser, som vidner om en særlig behandling af menneskeknoglerne. Den ordnede og regelrette måde, hvorpå fem knogledynger er anbragt $\mathrm{i}$ et dyssekammer ved Oldenbjerggård på Langeland, kunne tyde på, at der er tale om ægte sekundære begravelser, hvor 


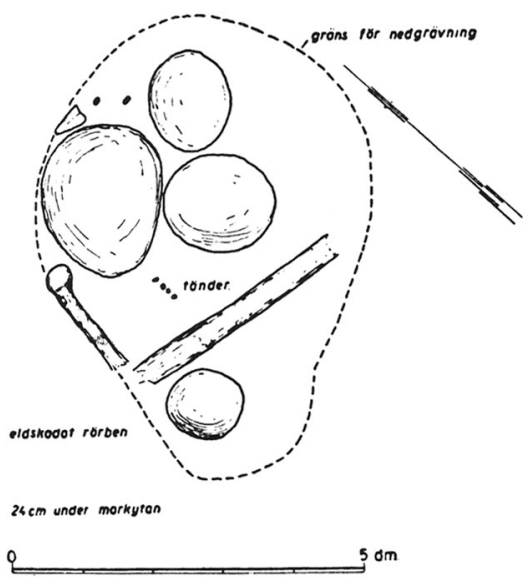

Fig. 16. Nedlæggelse af 4 kranier og rørknogler i en grube tæt ved en egentlig senneolitisk grav, Stockholmsgården, Skåne. (Efter Strømberg 1952).

Deposit of four skulls and various longbones in a pit close to a Late Neolithic grave, Stockholmsgården, Scania (after Strömberg 1952).

det var de afkødede knogledynger selv, som begravedes i kammeret. Hver af de fem tætte knoglebunker med kraniet øverst var anbragt på en stor flad sten med regelmæssige mellemrum. Hver dynge opfattedes af udgraveren, Jens Winther, som repræsenterende ét lig (Skaarup 1985 s. 132-33). Tilsvarende knoglebunker med knogler uden anatomisk orden kendes fra et dyssekammer i Nøbbet Vesterskov på det nordlige Lolland (Ebbesen 1988 s. 17-19) og i Baronens Høj i Nørreskoven på Als (Ebbesen 1975 s. 279). Også her må kødet være bortrådnet før den endelige placering, men det kan jo ikke siges, om kødets bortrådning er sket andetsteds eller i kammeret selv. En hellekiste eller muligvis et dyssekammer ved Kyndby i Horns Herred udgravedes i 1920 (21). Sammen med senneolitiske genstande fandtes også her knogler uden organisk orden. Lemmeknoglerne angiver mindst ni individer, og der var kraniefragmenter fra mindst fire individer, men kun én underkæbe.

Når man finder et skelet med benene afhugget ved skinnebenene og hænderne afhugget, som det er tilfældet $i$ en hellekiste ved Skedebjerggård nær ved Roskilde (Stürup 1962; Schiellerup 1991 s. 10), så er det vanskeligt at sige om man blot ville skaffe plads til den næste begravede, eller om man har ønsket at fjerne disse knogler til rituel brug (13). Det kan måske også tænkes, at den begravede er blevet henrettet på en uhyggelig måde. Det andet lig i samme hellekiste var delvist brændt.

Et skelet fundet og undersøgt i Føllenslev Mose ved Holbæk er nu C14-dateret til senneolitikum (calibreret 1945 f.Kr.). Skelettet lå ikke i organisk orden. Flere steder (bl.a. på kæbedele, arme og lår) findes hugspor, der viser, at nogle af knoglerne er overhugget. Da den overhuggede stump af højre underarm lå sammen med overarmen, må bløddele stadig have været på plads, da huggene faldt (Bennike \& Ebbesen 1987).

I forbindelse med en oprensing af Mollebakken mellem Aasø og Tyvelse i Sydsjælland fremkom i 1992 ikke mindre end 15 menneskekranier og kun én underkæbe samt forskellige andre, spredte menneskeknogler. Desuden fandtes mange dyreknogler samt træpæle, lerkarskår m.m. (22). Der er tale om et gam- 
melkendt offersted, idet der i 1932 opdagedes menneskeknogler samt en armring, der dateres til yngre bronzealder (Broholm \& Fischer-Møller 1934 s. 2425). Udfra den observerede stratigrafi og fundene selv er der næppe tvivl om, at dette sted er en plads, som benyttedes til ofringer igennem flere af oldtidens perioder. Da de nævnte kranier synes tilknyttet den ældste fundhorisont på stedet, og da der her fandtes lerkarskår, som af udgraveren bestemmes som neolitiske, må dette fund af åbenbart udvalgte knogler, betragtes som neolitisk. Resultaterne af en C14-analyse af knoglerne imødeses med forventning, således at dette fund kan dateres mere bestemt.

Også fra Skåne kendes knoglefund, der må afspejle ritualer i forbindelse med menneskeknogler. Tæt ved senneolitiske grave ved Stockholmsgarden fandtes to mindre gruber, hvor der i den ene lå fire kranier og et par rørknogler (fig. 16) og i den anden to kranier, en rørknogle og en bækkenknogle (Strömberg 1952 s. 173). Ved Solnäs, ligeledes Skåne er en tilsvarende nedlægning undersøgt (ibid. s. 182). Det bevidste udvalg af knogler antyder, at der næppe er tale om tilfældige udrømninger. Tæt ved sydsiden af Skogsdala-langdyssen ved Ystad er undersøgt seks gruber med menneskeknogler, der må anses for nedlæggelser af afkødede knogler (Jacobsson 1986 s. 101-103). Der er tale om rester af ikke mindre end 31 individer, hvor kranier og lange knogler synes at have haft en særlig bevågenhed. Disse knoglenedlæggelser, der dateres til senneolitisk tid eller ældre bronzealder, anses af udgraveren som knogler hentet fra en anden grav, måske ved en hellekistes udrømning.

Ved Gross Upahl i Mecklenburg er der gjort bemærkelsesværdige knoglefund, der fortæller om komplicerede ritualer med menneskeknogler i senneolitikum (Just 1960). Under en høj fandtes flere senneolitiske grave, hvoraf to stenrammegrave, grav 1 og 2, er af størst interesse. Grav 1 (ibid s. 58 ff) er en dyb rammegrav, hvor de høje sider nærmest fremtrådte som stenmure. I graven fandtes to begravelseslag adskilt af sten. I det øvre lag lå i en langstrakt bunke dækket af et stenlag, knoglerne af mindst syv individer, som oftest ej i anatomisk orden. Man har især tilstræbt at "bundte" de lange knogler efter gravens længderetning, gerne således at knogler, der ligner hinanden, lå sammen. Imellem disse bundter lå mindre knogler. En underarmsknogle var stukket igennem bækkenets skambenshul. En underkæbe var der også. Ovenpå dyngen fandtes seks kranier uden underkæber i to grupper à 3 stk. I det ene kraniums baghovedhul var stukket en underarmsknogle ind.

I det nedre knoglelag fremkom skeletdele af yderligere 14 individer, som lå $\mathrm{i}$ to bunker, en i hver ende af gravrummet. På hver bunke lå tre kranier, uden underkæber. Underkæber fandtes dog midt i knoglebunkerne, tre i den ene og fem i den anden. Knogler fra samme individ fandtes i begge bunker, det gælder især børnene. Imellem de to knoglebunker lå et fuldstændigt skelet af en kvinde i udstrakt rygleje. Den anden rammegrav, grav 2, var opbygget på ganske samme vis og med samme slags skeletfund som grav 1. Her markerede tværlagte lange knogler gravrummets midte (ibid. s. 67 ff). Generelt var der for fă underkæber. Alle menneskealdre fra børn til oldinge og begge køn er repræsenteret dog med en overvægt af mænd. Fundene daterer gravene til senneolitikum.

Fundene fra Gross Upahl må tydeligvis afspejle rituel omgang med menneskeknogler. Men hvad der præcis er foregået, og hvilke tanker der ligger bag, 
kan vi naturligvis kun gisne om. Der konstateredes ikke snit- eller hugspor på knoglerne, kun lidt musegnav. Langt størstedelen må være nedlagt, da de ikke mere holdtes sammen af bløddele. Abenbart er knoglerne samlet sammen, efter at ligene var helt eller delvis rådnet, for at blive placeret i de dybe rammegrave. Selvom forholdene med de mange knogler uden anatomisk orden umiddelbart kunne virke rodede, så øjner man dog i flere tilfælde orden og bevidste handlinger: I seks tilfælde lå tre kranier sammen, de lange knogler forekom oftest i bundter i gravenes længderetning, lårknogler er lagt omkring det hele skelets kranie. Udgraveren fremhæver (ibid. s. 82), at indtrykket var, at knoglerne ikke var smidt ned, men derimod omhyggeligt, pænt og systematisk var lagt ovenpå hinanden.

Selve gravformen - en dyb grav med stenramme, hvis sider næsten ligner mure og med to adskilte gravlag - kendes også i Danmark i Vest- og Midtjylland. Karakteristisk er, at der i samme gravgrube kan påvises to begravelser, som udfra de fundne flintdolke arkæologisk set er samtidige (Lomborg 1973 s. 114120). Der er ikke bevaret knogler i disse danske grave, og det er derfor ikke muligt at vurdere, i hvor høj grad der kan være tale om samme forhold, som ved Gross Upahl.

\section{Bronzealder}

Blandt de mest velkendte eksempler på rituel omgang med menneskeknogler i bronzealderen er gravfundet fra Stubberup på Lolland, hvor der i fylden over en dobbeltbegravelse fandtes spredte menneskeknogler (Lomborg 1964) samt Egtved-graven, hvor brændte ben af et 5-6-årigt barn lå ved Egtvedpigens fødder indhyldet $\mathrm{i}$ et stykke klæde og i en spånæske ved hovedet (Alexandersen m.fl. 1983). Da Egtvedpigen var for ung til at være moder til barnet, må dette regnes for et offer af en eller anden art.

Ligeledes fra ældre bronzealder kan nævnes et fund fra Löderup i Skåne (Strømberg 1975 s. 48) og et fund fra Sund i Nordtrøndelag (Farbregd, Marstrander \& Torgersen 1974), der utvivlsomt må opfattes som rituelle nedlægninger af knogler hentet andetsteds.

Lomborg (1964 s. 21 ff) opregner en lang række eksempler på fund af brændte ben i ældre bronzealders grave fra Tyskland og Danmark. Han fremhæver også tilstedeværelsen af marvspaltede knogler i højfylden til Kung Björns Hög i Uppland (yngre bronzealder, per. IV) som udtryk for rituel kannibalisme, og henviser til fund i tid svarende til vor ældre og yngre bronzealder fra Tjekkoslovakiet, hvor også børn er blevet fortæret (ibid. s. 25-26). Senere er publiceret et fund af denne art fra ældre bronzealder i Slovakiet (Vladár 1977), hvor man især har gjort meget ud af at sønderdele en barneunderkæbe.

Et hidtil upubliceret fund fra Strandgården i Hammer Bakker, Horns Herred, Nordsjælland (23), undersøgt i 1955, fortæller, at ritualer med menneskeknogler også fandt sted i Danmarks yngre bronzealder. I fordybninger øverst i en køkkenmødding fandtes flere dynger menneskeknogler. Den største dynge (fund 2) bestod af menneskeknogler uden organisk orden sammenblandet med skår af et beklasket lerkar fra yngre bronzealder (per. IV), samt dele af en underkæbe af hund (?) (fig. 17). Menneskeknoglerne er bestemt som tilhørende to voksne individer. En anden dynge (fund 1) indeholdt adskillige kraniefragmen- 

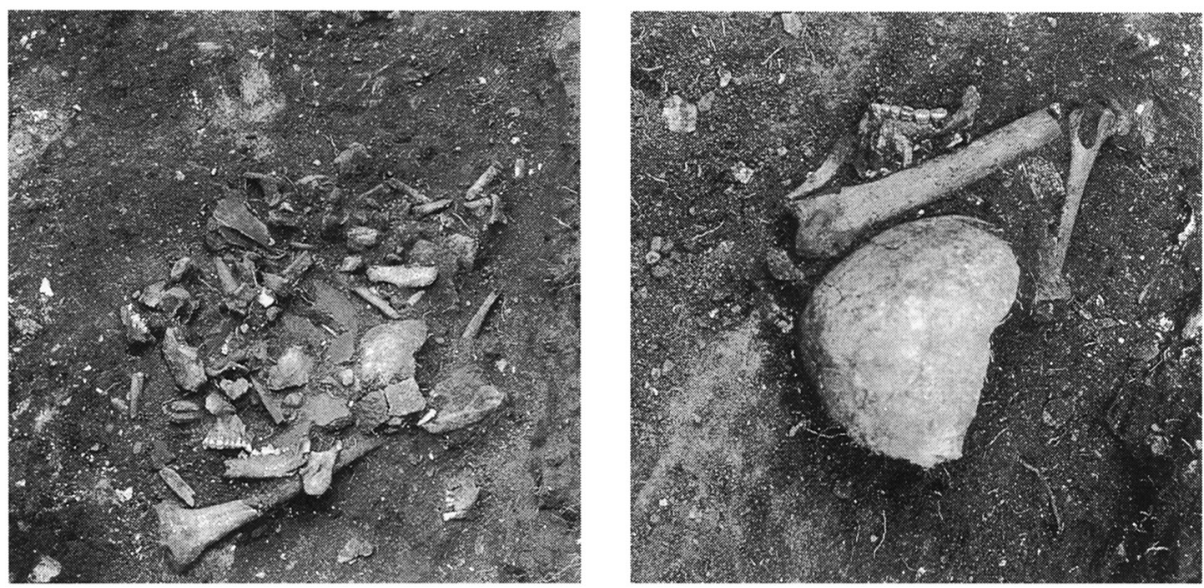

Fig. 17. Knogledynge fra Strandgården, Horns Herred, Sjælland, i to udgravningsstadier. Omkring kraniet er først lagt et par lange lemmeknogler, derefter de øvrige knogler. Foto: M. Orsnes.

Heap of bones from Strandgården, Horns Herred, Zealand, at two stages of excavation. First a pair of longbones were laid around the skull, followed by the remaining bones.

ter, øvre ende af et skinneben, et bækkenfragment, fragment af halshvirvel m.m. Enkelte af knoglerne fra Strandgården er behandlet på en måde, der tyder på kannibalisme. Et skinneben har således et meget kraftigt slagmærke og en underkæbe synes at være spaltet. Nogle af knoglerne er svedne. Hvorvidt fundet virkelig afspejler kannibalisme, eller det er udtryk for en partering og rituel nedlæggelse af knogler er dog et åbent spørgsmål.

Også vore moselig, fortrinsvis fra yngre bronzealder og førromersk jernalder, vidner om ritualer omkring lig. Disse er dog velbeskrevet såvel i den faglige som den populærvidenskabelige litteratur, og der er derfor ingen grund til ydeligere omtale her. Også fra en tidlig del af førromersk jernalder kendes et eksempel på nedlæggelse af knogler, hvis kød allerede var bortrådnet (Ebbesen 1987).

\section{Afsluttende bemærkninger}

Materialet fra megalitkulturen i store dele af Europa er fyldigt inddraget for at vise, at forhold som vi fra Danmark kun har forholdsvis fă vidnesbyrd om, optræder igen og igen. De diskussioner, der har været ført omkring de forskellige tolkninger af forholdene i megalitgravene, kan meget vel være af interese for forståelsen af et dansk og nordisk materiale. Også i Danmark/Skåne mangler der i nogle tilfælde visse knogletyper, hvilket må vise, at der er benyttet særlige knogletyper i indviklede begravelsesritualer. Herfra er der også fund, som kraftigt antyder, at bl.a. de store grøftanlæg var steder, hvor sådanne ritualer udførtes, og at der må have været en rituel og strukturel sammenhæng mellem disse anlæg og megalitgravene. Vidnesbyrdene fra de mange interessante knoglefund fra Norden og det øvrige Vesteuropa viser tillige, at man ikke nødvendigvis bør regne med én bestemt tolkning af forholdene. Der er ingenlunde tale om et "enten-eller", men snarere et "både-og". Der kan indenfor et givent område 
både være tale om begravelse af hele skeletter, af allerede afkødede knogler og om hentning af visse knogletyper til rituelt brug. Fundene fra bl.a. Frankrig og Orkney fortæller os, at selv ved megalitgrave indenfor et ganske snævert område er der væsentlige forskelle, som antyder flere typer af ritualer, hvor netop et samspil mellem de enkelte megalitgrave måske kan være årsagen.

Men både i Norden, i Tyskland, Frankrig og på De Britiske Øer ser det dog ud til, at det mest almindelige var begravelse af hele lig i megalitgravene med kød og bløddele (hvis knogler senere blev rodet rundt), og at man her har hentet bestemte knogletyper, kranier, underkæber eller de lange lemmeknogler, til brug ved ritualer andetsteds. Disse ritualer kunne bl.a. finde sted på de store grøftanlæg, hvor netop disse knoglekategorier har haft en særlig bevågenhed. Udelukkes kan det ikke, at visse knogler også kan have rejst den anden vej, eller de kan være benyttet i forbindelse med ritualer i moserne. Det er desuden et generelt træk i tragtbægerkulturen og samtidige europæiske kulturgrupper, at man har behandlet de afdødes knogler "pænt". Det er uhyre sjældent, at man har hugget knogler itu ved en egentlig partering. Det er åbenbart forrådnelsesprocessen, som er årsagen til, at de dødes knogler fragmenteredes. Hvis en knogle er knækket, er det snarest udtryk for "uheld", ikke for bevidst menneskelig indgriben i nedbrydningsprocessen.

Selvom det foreliggende nordiske materiale er begrænset, så kan der dog anes en tendens til, at man i løbet af mellemneolitikum er begyndt at udsætte knoglerne for en mere "hårdhændet" behandling i forbindelse med ritualerne. Det er mest fra en mere fremskreden del af mellemneolitikum, at vi finder nedlæggelser af brændte og til en vis grad knuste knogler i tilknytning til offerlagene (Trollasten, Hindby Mosse, Hagebrogård, Vroue Hede, Jordhøj). Måske hænger en sådan mulig ændring sammen med andre ændringer i stenaldersamfundene og deres ritualer. Det er jo netop i løbet af MN II, at de massive ofringer af keramik foran megalitgravene ophører og afløses af ofringer af andre oldsagstyper, der iøvrigt alle udsættes for en bevidst ødelæggelse ved brænding og knusning. Det er tillige først i en fremskreden del af mellemneolitikum, at vi finder vidnesbyrd, der bedst kan tolkes som ægte sekundærbegravelser i megalitgrave som Varpelev, hvor vi antagelig slet ikke har vidnesbyrd om denne jættestues primære brug. Man kunne måske her tillade sig at sammenligne med forholdene på Orkney, hvorom det er foreslået, at begravelser af afkødede knogler (ægte sekundærbegravelser) er et forholdsvis sent træk i megalitgravenes brug, repræsenteret ved Quanterness og Isbister. Både hvad angår Varpelev og de nævnte orcadiske megalitgrave kan de dér endeligt placerede knogler evt. være hentet $i$ andre megalitgrave.

Der er ingen vidnesbyrd fra de store grøftanlæg og megalitgravene, der tyder på kannibalisme. Nogle danske mosefund kunne tolkes i denne retning, men der foreligger intet egentligt bevis. Et enkelt østpreussisk fund fra snorekeramisk tid med marvspaltede armknogler (Happ 1991 s. 87 \& 271) kunne opfattes som et tegn på kannibalisme før senneolitikum/bronzealder.

Selvom der kan øjnes forskelle indenfor ritualerne i Vesteuropa på tragtbægerkulturens tid, så er de grundlæggende ligheder værd at bemærke. Ritualernes mangfoldighed kan også betragtes som et lighedspunkt over det store geografiske område. Netop skikken at bygge megalitgrave og opføre de store 
grøftanlæg, som vi kender fra hele Vesteuropa, bør til trods for deres morfologiske forskelligheder afspejle en til en vis grad ensartet holdning til de væsentlige spørgsmål omkring liv og død i de vesteuropæiske stenaldersamfund.

Først i senneolitikum og bronzealder ser vi både i Norden og andre steder $\mathrm{i}$ Europa flere træk, der fortæller om en mere hårdhændet behandling af de dødes jordiske rester. Spor efter egentlig partering, altså bevidst overhugning af knogler, kendes nu. Dertil kommer visse fund, som viser, at kannibalisme har faet fodfæste. Som nævnt ovenfor kan man muligvis ane, at en udvikling henimod en hårdere behandling af knoglerne i ritualerne allerede er begyndt i løbet af mellemneolitisk tid.

At der igennem hele neolitikum i store dele af Europa er udført ritualer med dele af menneskeskelettet, i særlig grad kranier, behøver ikke at undre, idet noget sådant er et særdeles udbredt fænomen i tid og rum. I mange "neolitiske" samfund har man også i nutiden udført komplicerede og langvarige begravelsesritualer med afkødede knogler, som det dog vil føre for vidt at komme ind på her. Selv indenfor det enkelte samfund kan der være tale om forskelligartet behandling af den døde: alder, køn, social position, dødsmåde, karakter og sympatier, ja endda den døendes eget ønske kan i visse tilfælde være udslaggivende (Joussaume 1987 s. 247-248; Happ 1991 s. 178).

Nogle af de ældste fund, der kan afspejle ritualer overhovedet, omfatter netop kranier. Et neanderthalkranium uden underkæbe fandtes således i en hule ved Monte Circio i Italien omgivet af en lille, rund stensætning. Andre neanderthalfund synes også at antyde en form for kraniekult (Bergounioux $1959 \mathrm{~s}$. 151-153; Happ 1991 s. 83-85). Længere oppe i tid er der ligeledes talrige vidnesbyrd om kraniers særlige betydning. Fra vore egne jernalders mosefund kendes hoveder uden kroppe, og kelterne var kendt som flittige hovedjægere. Også en mere "fredelig" brug af kranier kendes fra kelterne, hvor man på visse franske gravpladser har kunnet iagttage, at grave blev åbnet på et tidspunkt, da kødet var mere eller mindre bortrådnet, for at kraniet kunne fjernes, og i nogle tilfælde har man endda (efter brug) lagt kraniet ned i graven igen (Rozoy 1987 s. $55 \mathrm{ff})$.

Også i vor egen tid kendes en lang række tilfælde på ritualer omkring kranier eller kraniers særlig behandling. Vi kan blot nævne den katolske kirkes brug af helgenknogler. Den danske katolske kirkes vigtigste relikvie er martyrpaven Lucius hellige hjerneskal, som opbevares i Skt. Ansgars Kirke i København (Liebgott 1982 s. 178).

Men også mere almindelige menneskers kranier kunne fă en særlig behandling. I Bretagne brugte man indtil i forrige århundrede små tranportkasser til de nærmeste forfædres kranier, som man så kunne tage med hjem i familiens skød ved højtiderne.

I Hallstatt i Østrig kan man den dag i dag se kranierne efter landsbyens afdøde opstillet på rad og række, smukt bemalet med blomster og afdødes navn. Blandt kranierne kan identificeres Isidor Engel, som i forrige århundrede udførte de smukke og nøjagtige tegninger og akvareller til publikationen af gravene på den kendte Hallstatt-gravplads fra tidlig jernalder. Også en arkæologs kranium kan altså opnå rituel særbehandling. 


\section{NOTER}

1) Det er yderst beklageligt, at størstedelen af knoglefundene (bortset fra kranierne og visse lemmeknogler) fra de mange i ældre tid undersøgte megalitgrave er blevet kasseret. Herved er en uvurderlig kilde til forståelse af begravelsesskikke og ritualer tilknyttet vore megalitgrave for altid gået tabt. Det vil således ikke være muligt at vurdere antallet af individer eller om bestemte knoglekategorier er underrepræsenteret (se Bennike 1985 s. 468).

2) Sognebeskrivelsesnr. 32, Værløse Sogn, Københavns Amt. Sagen har Nationalmuseets j.nr. 3930/81, Nationalmuseets beretningsarkiv. Undersøgelsen lededes af museumsinspektør C.L. Vebæk. Denne artikels forfatter fungerede som udgravningsassistent sammen med stud. mag., nu mag. art. Bjarne Henning Nielsen, og stod for udarbejdelsen af udgravningsberetningen. Dyssetomten og en nærliggende langdysse havde ligget upåagtet, indtil skovrider E. Laumann Jørgensen, Københavns Skovdistrikt, identificerede dem i forbindelse med rydning af krat. Jeg skal her rette en tak til E. Laumann Jørgensen for hans bistand i forbindelse med den arkæologiske undersøgelse.

3) Hvor en megalitgrav er undersøgt genfindes ofte det træk, at en smuk bundbrolægning dækkes af et lag knust og/eller brændt flint, og forst ovenpå flinten finder man begravelserne. Det kan undre, at man i stenalderen har skabt en smuk og regelmæssig brolægning ikke til brug som leje for begravelserne, men åbenbart for straks efter at dække den med knust flint. Derfor kan bundbrolægningen og den knuste flint måske bedst opfattes som værende af praktisk betydning - herved skabtes en veldrænet kammerbund, der samtidig kunne stabilisere kammerets konstruktion. Men udstrøningen af brændt flint kan tillige have haft en eller anden rituel funktion. Brugen af knust flint som byggemateriale i vore megalitgrave er iøvrigt et fænomen, som man igen og igen træffer på, når højmassen undersøges (se f.eks. Strömberg 1971 s. $221 \mathrm{ff}$ og Kaul 1989).

4) Menneskeknoglerne er bestemt af dr. med. Jørgen Balslev Jørgensen.

5) Prøven, indsendt af skovrider E. Laumann Jørgensen på vegne af Værløse Museum, er dateret af Lunds Universitets Laboratorium for C 14-datering og har nr. Lu-1952.

6) Den velbevarede jættestue Jordehøj befinder sig i Stege Landsogn, Mønbo Herred, Præstø Amt, sognebeskrivelsesnr. 7. Undersøgelsen har Nationalmuseet j.nr. 6648/87. Restaureringen og den hertil knyttede arkæologiske undersøgelse af Jordehøj er en del af et større projekt, der udføres i samarbejde mellem Skov- og Naturstyrelsen og Nationalmuseet. Her udvælges betydningsfulde og velbesøgte megalitgrave, som behøver en istandsættelse, og restaureringsarbejdet og den arkæologiske dokumentation går hånd $\mathrm{i}$ hånd. Jeg takker konservator Svend Hansen og antikvar Torben Dehn, Skov- og Naturstyrelsen, for det gode samarbejde i dette projekt.

7) Knoglerne er bestemt af mag. scient. et lic. med. Pia Bennike, Panum-Instituttet.

8) Prøven er dateret af Svedberg-laboratoriet, Uppsala Universitet, og har nr. Ua-1908. Calibreringen efter Pearson \& Struever 1986.

9) Prøven er dateret af Nationalmuseets Cl4-laboratorium og har nr. K-5501.

10) Jeg takker Skibshøjgravens udgraver mag art. Erik Jørgensen for tilladelse til her at nævne dette ikke publicerede forhold ved dette gravfund.

11) Jeg skal her rette en varm tak til arkæolog Svend Aage Thornbjerg, Køge Museum, for at fă lejlighed til at drøfte de overordentligt betydningsfulde fund fra Varplelev-jættestuen med ham på stedet mens udgravningen stod på, og for tilladelse til at nævne samme i denne artikel. Svend Aage Thornbjerg har også gjort mig opmærksom på lighederne i fundsammenstæningen med Gundsølille-jættestuen. Lige ved siden af den nu undersøgte Varpelev-jættestue ligger en fredet jættestue, hvor vi desværre intet kender til fundforholdne i kammeret; jæunfør forhold ved et par megalitgrave fra Frankrig (La Hogue og La Hoguette) samt Orkney kunne man måske forestille sig, at knogler og det øvrige gravmateriale er hentet fra denne, og at de to megalitgrave, hvad angår nedlægninger af dødes jordiske rester og deres gravgods, strukturelt har virket sammen.

12) Restaureringen og undersøgelsen af jættestuen Nissehøj, Vellerup Sogn sognebeskrivelsesnr. 19, Horns Herred, Frederiksborg Amt, lededes af Torben Dehn og Svend Hansen, Skov-og Naturstyrelsen, mens Lars Holten, Nationalmuseet er ansvarlig for den arkæologiske dokumentation og beretning. Lars Holten takkes for tilladelsen til at nævne dette fund. Undertegnede deltog selv sammen med antropologen Pia Bennike i udgravningen af de nævnte kranier. Se iøvrigt Hansen 1993 s. 24-25.

13) Det er vel i sig selv umuligt i sådanne tilfælde at kunne skelne mellem, hvad der har været "praktisk" og "rituelt" i stenalderen, idet det forhistoriske menneske næppe har skelnet mellem disse begreber, således som vi i vor vestlige kultur har lært at gøre.

14) Jeg takker museumsinspektør Niels H. Andersen, Forhistorisk Museum, Moesgård, for nærmere oplysninger om dette Sarup-fund.

15) Jeg takker overinspektør Poul Otto Nielsen, Nationalmuseet for en drøftelse af forholdene på Bundsø.

16) Jeg takker museumsinspektør Niels H. Andersen, Forhistorisk Museum, Moesgård for tilladelse til at nævne det upublicerede kraniefund fra Sarup-anlægget ved Hygind. Dette anlæg er ganske kort nævnt i Arkæologiske Udgravninger i Danmark 1986, København 1987. Der er foreløbig blot tale om en mindre prøvegravning af en af det store anlægs grøfter, hvorved det er konstateret at bevaringsbetingelserne for 
knogler er optimale. Der ses med overordentlig stor interesse frem til en videre udgravning af dette Sarup-anlæg, som uden tvivl vil kunne give uvurderlige oplysninger om de rituelle aktiviteter i neolitikum.

17) Sarup-anlæggets underkæbe modsiger dette billede, men fortæller dog om interessen for udvalgte knogler på en sådan lokalitet.

18) Museumsinspektør mag. art. Arne H. Andersen takkes for tilladelse til at nævne dette upublicerede materiale.

19) Iøvrigt kender vi udmærkede vidnesbyrd om særlige ritualer med menneskeknogler, her igen især kranier, fra Mellemeuropas tidlige neolitiske kulturer. De optræder såvel i forbindelse med egentlige gravfund som på disse kulturers grøftanlæg (se f.eks. Happ 1991 s. 85, 87, 247, 291 \& 323-326; Kneipp \& Büttner 1988 s.489 ff; Kahlke 1954 s. 129-133; Jazdzewski 1965 s. 91-93; Dimitrescu 1957.

20) Også fra den senere del af neolitikum på De Britiske Øer kendes en række eksempler på, at menneskeknogler har indgået i ritualer. Nedlæggelser af menneskeknogler, nogle gange brændte, kendes fra hengemonumenterne og stencirklerne, i Sydengland f.eks. på Durrington Walls, Woodhenge og the Sanctuary ved Avebury (Wainwright 1971 s. 191; Burl 1987 s. 53-59) og i Skotland på Cairnpapple, Loanhead of Daviot og Cullerlie (Burl 1979 s. 132-137). Hvad angår den neolitiske gravskik og ritualer med knoglerne i Irland henvises til Cooney 1992 s. 128 ff med videre henvisninger samt til Burenhult 1984 s. 58 og Eogan 1986 s. 39 \& 177.

21) Kyndby, Kyndby Sogn, sognebeskrivelsesnr. 92, Horns Herred, Frederiksborg Amt; Nationalmuseet, 1. afd. j. nr. 579/47.

22) Undersøgelsen af denne moseofferplads blev forestået af Anne Bloch Jørgensen, Næstved Museum og David Robinson, Nationalmuseet. De takkes begge for tilladelsen til her at nævne dette fund og for drøftelser af fundforholdene. Stedet besigtigedes af undertegnede i efteråret 1992. Analyse af fundmaterialet samt C14-dateringer synes nu at angive, at de kranieførende lag hører til i yngre bronzealder.

23) Strandgården, Ferslev Sogn, sognebeskrivelsesnr. 236, Horns Herred, Frederiksborg Amt, NM I j.nr. 228/55, beretningsarkivet. Undersøgt af museumsinspektør Mogens Ørsnes. Knoglerne fra fund 2 er kortfattet bestemt af J. Balslev Jørgensen, Anthropologisk Laboratorium, mens de øvrige menneskeknogler er mere udførligt bestemt af Magnus Degerbøl, Zoologisk Museum.

\section{LITTERATUR}

Alexandersen, V., Bennike, P., Hvass, L., \& Stærmose Nielsen, K.-H., 1983: Egtved-pigen - nye undersøgelser. Aarbøger for nordisk Oldkyndighed og Historie 1981. København.

Andersen, N.H. 1981: Sarup. Befæstede neolitiske anlæg og deres baggrund. Kuml 1980. Højbjerg.

Andersen, N.H. 1988: Sarup, Befæstede kultpladser fra bondestenalderen. Århus.

Andersen, N.H. 1990 (a): Zwei befestigte Anlagen der Trichterbecherkultur. Jahresschrift für mitteldeutsche Vorgeschichte 73. Halle/Saale.

Andersen, N.H. 1990 (b): Sarup, Two Neolithic Enclosures in South-West Funen. Journal of Danish Archaeology 7, 1988. Odense.

Ashbee, P. 1966: The Fussel's Lodge Long Barrow, Excavations 1957. Archaeologia 100. London.

Ashbee, P. 1970: The Earthen Long Barrow in Britain. London.

Asmus, G. 1987: Menschliche Schädelfragmente aus der Grabung Bundsø-Flintholm. I: Hoika, J. 1987: Das Mittelneolithikum zur Zeit der Trichterbecherkultur in Nordostholstein, Offa-Bücher, Band 61. Neumünster.

Bauch, W. 1988: Eine Nachbestattung der Einzelgrabkultur mit Pferdeschädel in einem Megalithgrab von Borgstedt, Kreis Rendsburg-Eckernförde. Offa Band 45. Neumünster.

Becker, C.J. 1945: New Finds of hafted Neolithic Celts. Acta Archaeologica XVI. København.

Becker, C.J. 1947: Mosefundne Lerkar fra yngre Stenalder. Aarbøger for nordisk Oldkyndighed og Historie 1947. København.

Behrens, H. 1973: Die Jungsteinzeit im Mittelelbe-Saale-Gebiet, Veröffentlichungen des Landesmuseums für Vorgeschichte in Halle. Band 27, 1973. Berlin.

Behrends, H. 1991: Erdwerke der Jungsteinzeit in Bruchsal. Archäologische Informationen aus Baden-Württemberg, Heft 22. Stuttgart.

Beier, H.-J. 1984: Die Grab- und Bestattungssitten der Walternienburger und der Bernburger Kultur. Neolithische Studien III. Halle.

Beier, H.-J. 1991: Mittelneolitische Kollektivbestattungen im Mittelelbe-Saale-Gebiet und ihre Stellung innerhalb des mittel- und westeuropäischen Neolithikums, Bestattungswesen und Totenkult in ur- und frühgeschichtlicher Zeit, Herausgegeben von Fritz Horst und Horst Keiling. Berlin.

Bennike, P. 1985: Stenalderbefolkningen på øerne syd for Fyn, En antropologisk undersøgelse, i: Skaarup, J. 1985: Yngre Stenalder på øerne syd for Fyn. Meddelser fra Langelands Museum. Rudkøbing.

Bennike, P. 1990: Human Remains from the Grøfte Dolmen. Journal of Danish Archaeology 7, 1988. Odense.

Bennike, P. \& Ebbesen, K. 1985: Stenstrupmanden. Fra Holbæk Amt 1985. Holbæk. 
Bennike, P. \& Ebbesen, K. 1987: The Bog Find from Sigersdal. Human sacrifice in the Early Neolithic. Journal of Danish Archaeology, vol. 5, 1986. Odense.

Benson, D.G. \& Clegg, I.N.I. 1978: Cotswold burial rites. Man, New Series, Vol 13. London.

Bergounioux, F.M. 1958: "Spiritualité" de l'Homme de Néanderthal, Hundert Jahre Neanderthaler, 18561956, Gedenkbuch der internationalen Neanderthal-Feier. Köln.

Blomqvist, L. 1989: Megalitgravarna i Sverige, typ, tid, rum och social miljö. Theses and Papers in Archaeology, New Series, Published by the Institute of Archaeology at the University of Stockholm, 1. Stockholm.

Broholm, H.C. \& Fischer-Møller, K. 1934: Tre offerfund fra den yngre bronzealder. Nationalmuseets Arbejdsmark 1934. København.

Browall, H. 1986: Alvastra pålbyggnad, social och ekonomisk bas. Theses and Papers in North-European Archaeology 15. Stockholm.

Brøndsted, J. 1957: Danmarks Oldtid, Bind I, Stenalderen. København.

Burenhult, G. 1973: En Långdös i Hindby Mosse, Malmö. Malmöfynd vol. 2. Malmö.

Burenhult, G. 1981: Stenåldersbilder. Stockholm.

Burenhult, G. 1984: The Archaeology of Carrowmore. Theses and Papers in North-European Archaeology 14. Stockholm.

Burl, A. 1979: Rings of Stone, the Prehistoric Stone Circles of Britain and Ireland. London.

Burl, A. 1981: Rites of the Gods. London.

Burl, A. 1987: The Stonehenge People. London.

Chesterman, J.T. 1977: Burial rites in a Cotswold long barrow. Man, New Series vol. 12, no. 1. London.

Chesterman, J.T. 1979: Investigation of the human bones from Quanterness. I: Renfrew, C., 1979: Investigations in Orkney. Reports of the Research Commitee of the Society of Antiquaries of London no XXXVIII. London.

Cooney, G. 1992: Body Politics and Grave Messages: Irish Neolithic Mortuary Practices, Vessels for the Ancestors, Essays on the Neolithic of Britain and Ireland in honour of Audrey Henshall, ed. Sharples N. \& Sheridan A. Edinburgh.

Corcoran, J.X.W.P. 1967: The Excavation of Three Chambered Cairns at Loch Calder, Caithness. Proceedings of the Society of Antiquaries of Scotland vol. XCVII. Edinburgh.

Davidson, J.L. \& Henshall, A.S. 1989: The Chambered Cairns of Orkney. Edinburgh.

Davidson, J.L. \& Henshall, A.S. 1991: The Chambered Cairns of Caithness. Edinburgh.

Degerbøl, M. 1939: Dyreknogler. I: Mathiassen, T. 1939: Bundsø, en yngre Stenalders Boplads paa Als. Aarbøger for nordisk Oldkyndighed og Historie. København.

Drewett, P. 1977: The Excavation of a Neolithic Causewayed Enclosure on Offham Hill, East Sussex. Proceedings of the Prehistoric Society 43, 1976. Oxford.

Duday, H. \& Massset, C. 1989: Les sepultures collectives, Archéologie de la France. Paris.

Dumitrescu, H. 1957: Découvertes concernant un rite funéraire magique dans l'aire de la civilisation de la ceramique peinte du type Cucuteni-Tripolje. Dacia I, 1957. Bucuresti.

During, E. 1989: En osteologisk och antropologisk undersökning av tre skelettgravar från Bedingegravfältet. Stridsyxekultur i Sydskandinavien, Rapport från det andre nordiska symposiet om Stridsyxetid i Sydskandinavien 1988, red. Lars Larsson. University of Lund, Institute of Archaeology Report Series No. 36. Lund.

Ebbesen, K. 1975: Die Jüngere Trichterbecherkultur auf den Dänischen Inseln. Arkæologiske Studier vol. II. København.

Ebbesen, K, 1986: Døden i mosen. København.

Ebbesen, K. 1987: Bellevue-damen - Menneskeoffer i Bellevue Skov. Årbog for Historisk Samfund for Præstø Amt 1987. Præstø.

Ebbesen, K. 1988: Pederstrup Oldtidsminder. Lolland-Falsters Stiftsmuseum. Maribo.

Ebbesen, K. 1990: The Long Dolmen at Grøfte, South-West Zealand. Journal of Danish Archaeology 7 , 1988. Odense.

Eogan, G. 1986: Knowth and the passage-tombs of Ireland. London.

Farbregd, O., Marstrander, S. \& Torgersen, J. 1974: Bronsealders skjelettfund på Sund, Inderøy, NordTrøndelag, på bakgrunn av andre bronsealdersfunn. Det Kgl. Norske Videnskabers Selskab, Museet, Rapport, Arkeologisk Serie 1974, 3. Trondheim.

Forssander, J.E. 1936: Der ostskandinavische Norden während der ältesten Metallzeit Europas. Lund.

Giot, P.-R. 1983: The Megaliths of France, The Megalithic Monuments of Western Europe, ed. C. Renfrew. London.

Gräslund, B. 1989: Gånggriftarnas funktion i ljuset av primitiv själstro. Arkeologi och Religion, Rapport från arkeologidagarna 16-18 januari 1989, red. L. Larsson och B. Wyszomirska; University of Lund, Institute of Archaeology, Report Series no. 34. Lund.

Grupe, G. 1984: Verteilungsmuster von Skelettelementen in neolithischen Kollektivgräber als Ergebnis natürlicher Dekompositionsphänomene. Archälologisches Korrespondenzblatt 14, 1984. Mainz.

Hansen, S. 1990: Jættestuer i Gl. Præstø Amt. Miljøministeriet, Skov- og Naturstyrelsen, Rapport A 14. Hørsholm. 
Hansen, S. 1993: Jættestuer i Danmark. Hørsholm.

Happ, G. 1991: Bestattungen und Menschenreste in "Häusern" und Siedlungen des steinzeitlichen Mitteleuropa. Europäische Hochschulschriften, Reihe XXXVII, Bd. 33. Frankfurt am Main.

Hedges, J.W. 1984: Tomb of the Eagles, A Window on Stone Age Tribal Britain. London.

Heege, E. \& A. 1989: Die Häuser der Toten. Jungstenzeitliche Kollektivgräber im Landkreis Northeim. Hildesheim.

L'Helgouach, 1988: Le site Neolitihique final a fosses interromptus des prises a Machecoul, Loire-Atlantique. Enclosures and Defences in the Neolithic of Western Europe, ed. Colin Burges et alii. BAR International Series 403. Oxford

Henshall, A. 1985: The Chambered Cairns. The Prehistory of Orkney, Ed. C. Renfrew. Edinburgh.

Hoika, J. 1987: Das Mittelneolithikum zur Zeit der Trichterbecherkultur in Nordostholstein. Offa-Bücher, Band 61. Neumünster.

Jacobsson, B. 1986: The Skogsdala Dolmen. Meddelanden från Lunds Universitets Historiska Museum, New Series vol. 6, 1985-1986. Lund.

Jazdzewski, K. 1965: Poland. London.

Joussaume, R. 1988 (a): Dolmens for the Dead, London 1988.

Joussaume, R. 1988 (b): Analyse structurale de la triple enceinte de fosses interrompus a Champ-Durand, Nieul-sur-L'Autize, Vendee. Enclosures and Defences in the Neolithic of Western Europe, ed. Colin Burges et alii. BAR International Series 403. Oxford.

Just, F. 1960: Bericht über die Ausgrabungen im "Wendenkirchhof" von Gross Upahl, Kreis Güstrow. Jahrbuch für Bodendenkmalpflege in Mecklenburg 1960. Schwerin.

Jørgensen, E. 1977 (a): Brændende langdysser. Skalk nr. 5, 1977. Højbjerg.

Jørgensen, E. 1977 (b): Hagebrogård - Vroue - Koldkur, Neolitische Gräberfelder aus Nordwest-Jütland. Arkæologiske Studier vol. I., København.

Kahlke, D. 1954: Die Bestattungssitten des Donauländischen Kulturkreises der jüngeren Steinzeit, Teil I. Linienbandkeramik. Berlin.

Kaul, F. 1988: Neolitiske gravanlæg på Onsved Mark, Horns Herred, Sjælland. Aarbøger for nordisk Oldkyndighed og Historie 1987. København.

Kaul, F. 1989: Klekkendehøj og Jordehøj, 5000 årige ingeniørarbejder. Nationalmuseets Arbejdsmark 1989. København.

Kaul, F. \& Krogh K. 1990: En lidet påaget stenkløvningsteknik - og om oldtidsminder som stenbrud. Aarbøger for nordisk Oldkyndighed og Historie 1990. København.

Keiler, A. \& Piggott, S. 1938: Excavation of an Untouched Chamber in the Lanhill Long Barrow. Proceedings of the Prehistoric Society 4. Cambridge.

King, D.G. 1966: The Lanhill Long Barrow, Wiltshire, England. Proceedings of the Prehistoric Society 32. Cambridge.

Kirsch, E. 1991: Die Bestattungssitten der Kugelamphorenkultur in den Brandenburgischen Bezirken, Bestattungswesen und Totenkult in ur- und frühgeschichtlicher Zeit. Herausgegeben von Fritz Horst und Horst Keiling. Berlin.

Kjærum, P. 1969: Anmeldelse af Märta Strömberg: Der Dolmen Trollasten in St. Köpinge, Schonen. Fornvännen 1969. Stockholm.

Kjærum, P. 1970: Jættestuen Jordhøj. Kuml 1969. Højbjerg.

Kneipp, J. \& Büttner, H. 1988: Anthropophagie in der jüngsten Bandkeramik der Wetterau. Germania 66, 2 , 1988. Mainz.

Knöll, H. 1980: Sind die nordwestdeutschen Megalithgräber Ossuarien gewesen? Archäeologisches Korrespondenzblatt 10. Mainz.

Liebgott, N.-K. 1982: Hellige mænd og kvinder. Århus.

Liversage, D. 1965: En hellekiste ved Gerdrup, Københavns Amt. Aarbøger for nordisk Oldkyndighed og Historie 1964. København.

Liversage, D. 1966: Stemningsfuld begravelse. Skalk nr. 3 1966. Højbjerg.

Liversage, D. 1980: Material and Interpretation, The Archaeology of Sjælland in the Early Roman Iron Age. Publications of the National Museum, Archaeological- Historical Series I, vol XX. København.

Lomborg, E. 1964: Gravfund fra Stubberup, Lolland. Kuml 1963. Århus.

Lomborg, E. 1973: Die Flintdolche Dänemarks. Nordiske Fortidsminder, Serie B - in quarto - Bind 1. København.

Lüning, J. 1968: Die Michelsberger Kultur. Ihre Funde und räumlicher Gliederung. Bericht der RömischGermanischen Kommision 48, 1967. Berlin.

Madsen, A.P. 1896: Gravhøje og Gravfund fra Stenalderen i Danmark, I, Det østlige Danmark. København.

Madsen, A.P. 1900: Gravhøje og Gravfund fra Stenalderen i Danmark, II, Fyen og Jylland. København.

Maier, R.A. 1962: Fragen zu neolitischen Erdwerken Südbayerns. Jahresbericht der Bayerischen Bodendenkmalpflege 1962. München. 
Mathiassen, T. 1939: Bundsø, en yngre Stenalders Boplads paa Als. Aarbøger for nordisk Oldkyndighed og Historie. København.

Mercer, R.J. 1975: Hambledon Hill. Current Archaeology vol. V, no. 1. London.

Mercer, R.J. 1980: Hambledon Hill - a Neolithic Landscape. Edinburgh.

Mercer, R.J. 1988: Hambledom Hill, Dorset, England. Enclosures and Defences in the Neolithic of Western Europe, ed. Colin Burges et alii. BAR International Series 403. Oxford.

Mercer, R.J. 1990: Causewayed Enclosures. Risborough.

Midgley, M. 1992: TRB Culture, The First Farmers of the North European Plain. Edinburgh.

Mohen, J. P. 1989 : Le Monde des Megalithes. Paris.

Müller, C. 1960: Anthropologische Bemerkungen zu den bei Gross Upahl, Kreis Güstrow, ausgegrabenen Skeletten. Jahrbuch für Bodendenkmalpflege in Mecklenburg 1960. Schwerin.

Müller, D.W. 1988: Grabkammer vom mitteldeutschen Typ mit Menhir von Langeneichstädt, Kr. Querfurt. Ausgrabungen und Funde 33, 1988. Berlin.

Müller, D.W. 1991: Nichtmegalitische Kollektivgräber der Bernburger Kultur. Ein Beitrag zur Ossuariendiskussion. Bestattungswesen und Totenkult in ur- und frühgeschichtlicher Zeit. Herausgegeben von Fritz Horst und Horst Keiling. Berlin.

Nielsen, P.O. 1981: Stenalderen. Sesams Danmarkshistorie. København.

Nielsen, P.O. 1984: Flint axes and megaliths - the time and context of the Early Dolmens in Denmark. The Archaeology of Carrowmore. Theses and Papers in North-European Archaeology 14. Stockholm.

Piggott, S. 1962: The West Kennet Long Barrow, Ministry of Works Archaeological Reports no. 4. London. Pryor, F. 1976: A Neolithic Multiple Burial from Fengate. Peterborough. Antiquity 50. Cambridge.

Raddatz, K. 1979: Zur Funktion der Grosssteingräber. Grosssteingräber in Nierdersachsen. Herausgegeben von Heinz Schirnig, Veröffentlichungen der Urgeschichtlichen Sammlungen des Landesmuseums zu Hannover. Hildesheim.

Renfrew, C. 1979: Investigations in Orkney. Reports of the Research Commitee of the Society of Antiquaries of London no XXXVIII. London.

Richards, C. 1988: Altered Images: A Re-examination of Neolithic Mortuary Practices in Orkney. The Archaeology of Context in The Neolithic and Bronze Age: Recent Trends, ed.: J.C. Barret \& I.A. Kinnes. Sheffield.

Rozoy, J.-G. 1987: Les Celtes en Champagne, vol 1. Charleville-Mézieres.

Rydbeck, O. 1931: En trepanation i Skåne för 3000 år sedan och dess orsaker. Meddelanden från Lunds Universitets Historiska Museum 1931. Lund.

Saville, A. 1990: Hazleton North, Gloucerstershire, 1979-82: The excavation of a Neolithic long cairn of the Severn-Cotswold group. English Heritage, Archaeological Report no. 13. London.

Schiellerup, P. 1991: Senneolitisk gravkeramik - et upåagtet gravudstyr. ROMU, Årsskrift for Roskilde Museum, 1990. Roskilde.

Schiellerup, P. 1992: St. Valbyvej - et senneolitisk højkompleks ved Himmelev nord for Roskilde. Aarbøger for nordisk Oldkyndighed og Historie 1991. København.

Schuldt, E. 1966 (a): Der Grossdolmen von Liepen, Kreis Rostock. Bodendenkmalpflege in Mecklenburg, Jarhbuch 1966. Rostock.

Schuldt, E. 1966 (b): Die Ganggräber von Liepen, Kreis Rostock. Bodendenkmalpflege in Mecklenburg, Jarhbuch 1966. Rostock.

Schuldt, E. 1972: Die Mecklenburgischen Megalithgräber. Berlin.

Schuldt, E. 1973: Die Grosssteingräber von Friedrichsruhe, Kreis Parchim. Bodendenkmalpflege in Mecklenburg, Jahrbuch 1972. Berlin.

Scott, J.G. 1992: Mortuary Structures and Megaliths, Vessels for the Ancestors. Essays on the Neolithic of Britain and Ireland in honour of Audrey Henshall, ed. Sharples, N. \& Sheridan, A. Edinburgh.

Serner; A. 1938: On "Dyss" Burial and Beliefs about the Dead During the Stone Age with special regard to South Scandinavia. Lund.

Sharples, N.M. 1985: Individual and Community: The Changing Role of Megaliths in the Orcadian Neolithic. Proceedings of the Prehistoric Society 51. Cambridge.

Sharples, N.M. 1986: Radiocarbon dates from three chambered tombs at Loch Calder, Caithness. Scottish Archaeolocial Review vol. 4. Edinburgh.

Skaarup, J. 1985: Yngre Stenalder på øerne syd for Fyn. Meddelser fra Langelands Museum. Rudkøbing.

Smith, I.F. 1965: Windmill Hill and Avebury - Excavations by Alexander Keiler 1925-39. Cambridge.

Strömberg, M. 1952: Die Bestattungsformen in Schonen während des Spätneolitikums. Meddelanden från Lunds Universitets Historiska Museum 1962. Lund.

Strömberg, M. 1968: Der Dolmen Trollasten in St. Köpinge, Schonen. Acta Archaeologica Lundensia series in 8., no. 7. Lund.

Strömberg, M. 1971: Die Megalithgräber von Hagestad. Acta Archaeologica Lundensia series in 8., no 9. Lund.

Strömberg, M. 1973: Megalithgräber bei Hagestad. Megalithic Graves and Ritual (ed. G. Daniel \& P. 
Kjærum), Papers presented at the III Atlantic Colloquium, Moesgård 1969, Jutland Archaeological Society Publications XI. København.

Strömberg, M. 1975: Studien zu einem Gräberfeld in Löderup. Acta Archaeologica Lundensia. Series in 8. No 10. Lund.

Stürup, B. 1962: Stenalderdrama. Skalk nr. 1 1962. Højbjerg.

Thorsen, S. 1981: "Klokkehøj" ved Bøjden. Et sydvestfynsk dyssekammer med bevaret primærgrav. Kuml 1980. Århus.

Thorvildsen, K. 1939: Dobbeltjættestuen paa Kyndeløse Mark. Nationalmuseets Arbejdsmark 1939. København.

Thorvildsen, K. 1941: Dyssetidens Gravfund i Danmark. Aarbøger for nordisk Oldkyndighed og Historie 1941. København.

Verheyleweghen, J. 1962: Un Dépôt Funéraire de Crâne Néolithique à Spiennes. Helenium II. Wetteren.

Vladár, J. 1977: Zur Problematik der befestigten Siedlungen der Ausgehenden älteren Bronzezeit in der Slowakei. Festschrift zum 50jährigen Bestehen des Vorgeschichtlichen Seminars Marburg. Marburger Studien zur Vor- und Frühgeschichte, Band 1. Gladenbach.

Wainwright, G.J. 1971: Durrington Walls: Excavations 1966-1968. Reports of the Research Committee of the Society of Antiquaries of London No. XXIX. London.

Wegewitz, W. 1960: Eine Schädelbestattung der Einzelgrabkultur. Nachrichten aus Niedersachsens Urgeschichte 29 . Hildesheim. 


\section{Neolithic Rituals involving Human Bones}

In 1981 a destroyed dolmen was excavated at Trekroner in eastern Zealand (figs. 1-3). The burial layer appeared to be intact, and the examination of the bones showed that at least 10 individuals were represented -5 adults and 5 children. Each was represented only by a small number of bones, and this applied especially to the children, who were represented mostly by their lower jaws. There were only a few small pieces of the skulls themselves; also the long bones were sparingly represented. A C14 assay gave the calibrated value of $328($ ) B.C. It is probable that some more characteristic bones, especially skulls and long bones, had been removed for ritual use elsewhere.

In 1988 the passage grave "Jordehøj" on the island of Mon was excavated (Kaul 1989; Hansen 1993) (fig.4). At the top of the mound was found a posthole on the bottom of which there lay a collection of human bones from one or two individuals (including bones from fingers and pelvices), which obviously represented a ritual deposit of excarnated bones. One of the bones has been dated to 258() B.C. (calibrated), which indicates Single Grave times. The deposition itself could have been made later, perhaps in the Late Neolithic, when the mound was enlarged.

\section{Funnel Beaker Culture and Cultural Groups contemporary with it}

A number of finds from graves of the northern Funnel Beaker Culture indicate special treatment of certain parts of the skeleton. For example the skull of the primary burial in the dolmen, "Klokkehøj", on Funen was missing, though the mandible was still present (Thorsen 1981).

The skeletal material from the passage grave, "Carlshögen" in SE Scania may be taken as an example of ritual treatment of human bones in the Funnel Beaker Culture (Strömberg 1971). Under the primary floor layer was found a "three-armed" pit (fig. 8), each of whose arms contained excarnated bones of a number of different individuals, including in one arm a skull without mandible. Presumably this was some kind of dedicatory sacrifice made when the passage grave was constructed. A similar pit was found below the chamber of a passage grave at Ingelstorp, Scania. Together with the sacrificial stratum belonging to the dolmen at Hindby Mosse in Scania were found sniall heaps of burnt and broken bones, nearly all fragments of human skulls (Burenhult 1973). Similar discoveries of burnt and comminuted human bones are known from the sacrificial areas of a couple of passage graves in Jutland.

Recently at Varpelev in eastern Zealand there was excavated a passage grave with chamber contents intact and the bones in a good state of preservation. The human skeletal material from the Middle Neolithic burial layer was lightly burnt and occurred in heaps without organic order. In the heaps were also found sherds of pottery, and flint artifacts, of-ten in a burnt condition as well. A reasonable explanation would be that both the bones and much of the pottery and flint were fetched from elsewhere and placed in the chamber in a lightly burned condition.

Although finds from the northern Funnel Beaker Culture, which document that rituals took place connected with particular selected bones, are emphasised, it should be remembered that there are also finds showing that the chambers of megalith tombs were used for "normal" interments of complete bodies. The bones seldom lie in anatomical order because they have been cleared up and arranged, and because of natural decay. Nevertheless there is much to indicate that the bones were in some cases taken out of the tombs to be used at rituals elsewhere. Such an "elsewhere" could be the causewayed enclosures, of which 22 are now known in I)enmark (Andersen 199()(a)). The activities which took place at these sites included ritual use of human bones. Cranial parts and a mandible were found in the ditch segments at Sarup itself, and in the postholes of a semi-circular structure inside the enclosure there were found burnt human bones without skulls and mandibles. From the causewayed enclosure at Bundso in southern Jutland came several finds of parts of crania, but never mandibles. Similar observations have been made at the causewayed enclosure at Hygind on Funen, where human skulls without jaws were 
found together with cattle skulls and other contents. It is attractive to contrast the deficiency at the last two localities with the surplus of mandibles in megalithic tombs, as for instance at Trekroner.

Also in Germany and other countries aspects of the skeletal material from megaliths have been a subject of discussion. On the basis of material from Mecklenburg, Schuldt (1972) proposed that there must have been secondary burials proper, because he had excavated heaps of bones without organic relationship, often with the skulls uppermost. Conversely Grupe (1984) has been able to show that material, which gives the immediate impression of being unrelated, and therefore potentially an indication of secondary burial, at times only reflects tidying up processes and natural decay. From several German causewayed enclosures there are known burials (fig. 1()) and depositions of bones (fig. 11), which indicate the ritual use of human bones.

Also in France conditions are not fully clear. There are megaliths in which burials of complete skeletons survive, while on the other hand there are many tombs in which the bones lie without organic order. In a megalith at La Houge in Normandy the bones were in complete disorder, and there were 8 mandibles without a single skull. It is noteworthy that many of the skeletons in the tomb of La Hoguette only a few hundred meters away were articulated and complete. The relationship between these two contemporary tombs is interpreted to be that when the chamber of $\mathrm{La}$ Hoguette was filled up, the bones were collected together and placed in the chamber at La Houge, while some of them, for instance the skulls, were retained and taken to the dwelling site or perhaps to a causewayed camp. Also the French causewayed enclosures have provided clear evidence of rituals involving human bones involving depositions of skulls without jaws or jaws without the rest of the skull.

Well published bone reports are also available from megalithic tombs in the British Isles, and in several cases certain categories of bones are missing. The long barrow at West Kennet in southern England deserves especial mention (Piggott 1962). Here there were too many mandibles compared with skulls, and far too few long bones. Also at Hazleton North it could be established that bodies were buried complete. In this case too some bones were missing, specifically some long bones and probably skulls. Bones are missing as well from other megaliths in the area.

Important discoveries at several of the British causewayed enclosures show that rituals took place connected with bones. For instance in the primary deposits in the ditches at Hambledon Hill were found many deposits of human skulls without cervical vertebrae attached to them (Mercer 1975). The lower jaws were nearly always missing. We find that the categories of bone there are too few of in the megalithic tombs are those there are too many of in the causewayed enclosures, just as we have observed in the much poorer I)anish material.

From Orkney megaliths we have good skeletal material showing that both single, already de-fleshed bones (Quanterness), and complete skeletons (e.g. Midhowe) were buried. It is not impossible that the megaliths in which each individual is represented only by a few disarticulated bones, had transferred to them bones from other tombs. In tombs like Isbister (fig. 12), Midhowe, and Knowe of Yarso (fig. 13) the arrangement of the bones can be seen not only as expressing a practical wish for tidiness, but also as an expression of rituals around particular bones of the anatomy. It can also be seen in Orkney that certain bones are missing; again they must have been taken away for use elsewhere. Skulls are often under-represented, while lower jaws are entirely absent in one of the tombs.

\section{Single Grave Culture, Late Neolithic, Bronze Age}

A small number of discoveries tell of rituals connected with human bones in Single Grave times. At the Scanian cemetery at Bedinge was excavated a grave in which a female skeleton was accompanied by a considerable number of bones without organic connection, including five skulls without lower jaws (1)uring 1989). Another interesting find comes from Metzendorf-Voxdorf in northwestern Germany, where a skull had been deposited alone in a bowl covered by a beaker (fig. 14) (Wegewitz $196(0)$

Indications of rituals connected with human bones are also known from Late Neolithic times. An example comes from Lille Vasby in eastern Zealand. Together in a single grave were found parts of the skeletons of three individuals, of which the skulls and most of the long bones were missing (Liversage 1966; 1980). The bones must have been removed after the dissolution of the connecting tissue 
(fig. 15). They could possibly have been the bones found in a nearby pit. There were also a number of separate skulls. The skulls of children seem to have been of particular interest at these rituals.

In many Late Neolithic stone cists the bones have been removed from the interior to give room for later burials, but in cases where there is no final articulated burial and all the bones are mixed together, it must be concluded that the cist was opened a last time with some other purpose than nomal burial. Similar observations have been made in Late Neolithic burial deposits in dolmens. At some sites in Scania depositions of skulls close to Late Neolithic graves are also known (fig. 16).

In a pair of deep, stone-lined graves at Gross Upahl, Mecklenburg, there were found bones indicative of complex rituals surrounding secondary burials of already defleshed bones. There were two layers with bones of many individuals, often with skulls without jawbones uppermost in the heaps.

There are also examples from the Bronze Age of ritual treatment of human bones (Lomborg 1964), among which the burnt bones of a child found in the grave at Egtved should be mentioned. Some of these finds may imply ritual cannibalism, as in the case of an as yet unpublished discovery from Strandgarden, Horns Herred, Zealand, where two heaps of disarticulated bones were heaped against skulls (fig. 17). Discoveries in other parts of Europe suggest that camnibalism entered the scene in the Late Neolithic and Bronze Age.

\section{Conclusions}

Whether we examine south Scandinavia or other places in western Europe during the Fumnel Beaker Culture and groups contemporary with it, we find that bones are absent from the graves in a way which shows that certain categories more than others were objects of ritual interest. The finds also show a ritual and structural connection between the graves and the causewayed enclosures. The megalithic tombs and the finds in them tell us that we ought not to limit ourselves to a single interpretation of grave customs. In the same area can occur burial of complete bodies, of excarnated bones, and the removal of particular bones for ritual purposes. Instances both in France and Orkney tell that even in very limited areas there can be substantial differences, suggesting different types of rituals, of which a cause could be an interplay between different tombs.

In south Scandinavia, Germany, France, and the British Isles it looks as if the burial of complete bodies in megaliths was the commonest, and that they were disturbed later, and that particular types of bone were taken away skulls, jaws, or long limb bones. These were used for ritual purposes at the causewayed enclosures and perhaps elsewhere, at places where these bones are preferentially found. Also it is a common trait in the Funnel Beaker Culture and its contemporaries in Europe that the bones of the departed were treated with respect. It is very rare to find signs of their having been chopped across. It is clearly processes of decay that led to their fragmentary condition.

It is not until the Late Neolithic and Bronze Age that we find indications in northern Europe and elsewhere of rougher treatment, and traces of cutting up are now found. Also there are a number of finds that suggest the occurrence of camnibalism. A development towards rougher treatment of bones can possibly be detected as early as the Middle Neolithic.

\author{
Flemming Kaul \\ Nationalmuseet \\ Oversattelse: David Liversage
}

